\title{
Impacts of management on soil biota in Vertosols supporting the broadacre grains industry in northern Australia
}

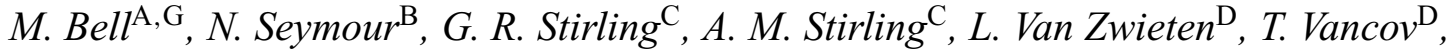 \\ G. Sutton ${ }^{\mathrm{E}}$, and P. Moody ${ }^{\mathrm{F}}$ \\ ${ }^{A}$ Queensland Department of Primary Industries and Fisheries, J. Bjelke-Petersen Research Station, \\ PO Box 23, Kingaroy, Qld 4610, Australia. \\ ${ }^{B}$ Queensland Department of Primary Industries and Fisheries, Leslie Research Centre, PO Box 2282, \\ Toowoomba, Qld 4350, Australia. \\ ${ }^{C}$ Biological Crop Protection Pty Ltd, 3601 Moggill Rd, Moggill, Qld 4070, Australia. \\ ${ }^{\mathrm{D}} \mathrm{New}$ South Wales Department of Primary Industries, Wollongbar Agricultural Institute, \\ 1243 Bruxner Highway, Wollongbar, NSW 2477, Australia. \\ ${ }^{\mathrm{E}}$ Landmark Pty Ltd, Dalby, Qld 4405, Australia. \\ ${ }^{\mathrm{F}}$ Queensland Department of Natural Resources, Mines and Water, Meiers Rd, Indooroopilly, \\ Qld 4068, Australia. \\ GCorresponding author. Email: Mike.Bell@dpi.qld.gov.au
}

Abstract. The grain-producing regions of northern New South Wales and southern and central Queensland are characterised by cropping systems that are strongly dependent on stored soil moisture rather than in-crop rainfall, and tillage systems that are increasingly reliant on zero or minimum tillage. Crops are grown relatively infrequently and crop rotations are dominated by winter and summer grains (wheat [Triticum aestivum L.] and sorghum [Sorghum bicolor L. Moench], respectively), with smaller areas of grain legumes and cotton (Gossypium hirsutum L.). The grey, black, and brown Vertosols represent the more productive soils in the region under rainfed cropping, and are the focus of work reported in this study.

Soil samples were collected from surface soils $(0-0.30 \mathrm{~m})$ across the region, utilising sites of long term tillage and residue management studies, fertiliser trials, and commercial fields to enable an assessment of the impact of various management practices on soil biological properties. A number of biological and biochemical parameters were measured (microbial biomass $\mathrm{C}$, total organic $\mathrm{C}$ and labile $\mathrm{C}$ fractions, total $\mathrm{C}$ and $\mathrm{N}$, microbial activity using FDA, cellulase activity, free living nematodes, total DNA and fatty acid profiles), and the response of wheat, sorghum, and chickpea (Cicer arietinum L.) to steam pasteurisation was assessed in glasshouse bioassays. The objective was to obtain an indication of the biological status of grain-growing soils and assess the impact of biological constraints in soils from different regions and management systems.

Results showed that biological activity in cropped soils was consistently low relative to other land uses in northern Australia, with management practices like stubble retention and adoption of zero tillage producing relatively small benefits. In the case of zero tillage, many of these benefits were confined to the top $0.05 \mathrm{~m}$ of the soil profile. Fallowing to recharge soil moisture reserves significantly reduced all soil biological parameters, while pasture leys produced consistent positive benefits. Breaking a long fallow with a short duration grain or brown manure crop significantly moderated the negative effects of a long bare fallow on soil biology. Use of inorganic $\mathrm{N}$ and $\mathrm{P}$ fertilisers produced minimal effects on soil biota, with the exception of one component of the free-living nematode community (the Dorylaimida).

The glasshouse bioassays provided consistent evidence that soil biota were constraining growth of both grain crops (sorghum and wheat) but not the grain legume (chickpea). The biota associated with this constraint have not yet been identified, but effects were consistent across the region and were not associated with the presence of any known pathogen or correlated with any of the measured soil biological or biochemical properties. Further work to confirm the existence and significance of these constraints under field conditions is needed.

None of the measured biological or biochemical parameters consistently changed in response to management practices, while conflicting conclusions could sometimes be drawn from different measurements on the same soil 
sample. This highlights the need for further work on diagnostic tools to quantify soil biological communities, and suggests there is no clear link between measured changes in soil biological communities and economically or ecologically important soil attributes.

Additional keywords: plant growth, wheat, sorghum, chickpea, bioassays.

\section{Introduction}

The broadacre grain cropping areas of north-eastern Australia (northern New South Wales, southern and central Queensland) occupy an area of approximately 4 Mha (Anon. 2004). Farming systems vary significantly across the region. In the areas of higher/more reliable rainfall of the east, cropping is the dominant land use, but further west, mixed cropping and grazing enterprises are more common, with cropland rotated with grazed pasture phases. Cropping intensity varies from c. $15 \%$ in the southern and eastern parts of region to only c. 5-8\% in the western and northern areas where rainfall is less reliable. The dominant summer crops in the region are sorghum (Sorghum bicolor L. Moench s. lat.) and cotton (Gossypium hirsutum L.), whereas wheat (Triticum aestivum L.) and chickpea (Cicer arietinum L.) are the main winter crops. Mungbean (Vigna radiata (L.) Wilczek), barley (Hordeum vulgare L.), and maize (Zea mays L.) are also important in some areas. Despite this variety of crop options, cereal grains represent $80-90 \%$ of the cropped area in most seasons (Anon. 2002).

Availability of water is the main factor limiting crop productivity across the region. Annual rainfall is extremely variable, especially in the north and west, with the result that cropping systems have increasingly evolved around opportunistic cropping rather than fixed rotations (Freebairn et al. 1997). Subsoil moisture reserves are an important factor in determining crop performance, as growing seasons are often characterised by extended periods without effective rainfall. Fallowing has traditionally been used to replenish soil water reserves between crops. Bare fallows of 12-18 months are common, with the amount of stored soil moisture increasingly being used to determine the occurrence of a planting event. Fallows of 12-15 months are also commonly used during the transition from summer to winter crops in the rotation (e.g. sorghum harvested in autumn, with wheat, chickpea or barley sown in winter the following year). Improved efficiency of water capture and use by crops as a result of conservation tillage and direct drill practices have been credited with increasing system productivity (e.g. Felton et al. 1995; Radford et al. 1995). In addition, simulation studies consistently suggest increased cropping frequency is possible with an opportunity cropping strategy combined with direct drill, controlled traffic systems (Chudleigh et al. 2002)

The main cropping areas (Webb et al. 1997) are centred on grey, brown, or black Vertosols; red or brown Sodosols; and red or brown Chromosols (Isbell 1993). The work reported in this paper is centred on cropped Vertosols across the region. These soils are characterised by relatively high plant available water holding capacity (PAWC $>20 \mathrm{~mm}$ plant available water/0.1 m profile depth; Webb et al. 1997) and, in their virgin state, moderate to high levels of chemical fertility. However sustained cropping, initially using conventional tillage (CT) but in recent years employing reduced or zero tillage (ZT) practices, has resulted in a decline in soil chemical fertility so that chemical fertiliser applications [especially nitrogen $(\mathrm{N})$ and phosphorus $(\mathrm{P})$ ] are necessary to sustain productivity (Dalal and Probert 1997).

Research has been conducted in the northern region on specific functional components of the soil biota, with particular emphasis on soil-borne diseases, plantparasitic nematodes, and mycorrhizae (e.g. Peck et al. 1993; Thompson 1994; Burgess et al. 1996; Wildermuth et al. 1997; Thompson et al. 1999; Kirkegaard et al. 2003). However, less work has been done to identify biota that can potentially moderate the impact of pathogens on crops in the farming system (e.g. Duczek and Wildermuth 1991). Similarly, there has been extensive research to investigate the interactions between cropping systems and the beneficial impact of soil macrofauna (Radford et al. 1995; Wilson-Rummenie et al. 1999) and mycorrhizae, (Thompson 1987), but other beneficial components of the soil biota have received limited (Roper et al. 1994) or no attention. In particular, there has been little concerted effort to explore the broader impact of crops and cropping systems on the constituents and relative activities of biota constituting the detritus food web, and the impact of any changes on subsequent crop productivity.

The aim of this research was to quantify the impact of common management practices (fallows, ley pastures, tillage systems, fertiliser use) on the general soil biota and specific plant pathogens in cropping systems on northern Vertosols. The effect of the biological community established under contrasting management systems on the productivity of sorghum, wheat, and chickpea (the dominant crops in the farming system) was investigated by examining relationships between various biological parameters and the plant growth responses obtained in glasshouse assays when soil was partially sterilised with steam.

\section{Materials and methods}

\section{Experimental sites}

Soil samples were collected from commercial fields in close proximity to each other that had experienced contrasting crop management practices. 
Uncropped (i.e. native/undisturbed pasture) reference sites, together with long-term tillage, fertiliser, or rotation trials, were also sampled when available. Details of the commercial sites (locations and recent site history) and brief descriptions of the long-term trials are shown in Table 1.

More detailed descriptions of the tillage trials at Warwick (Hermitage) and Biloela are available in Thomas et al. (2003) and Radford et al. (1995), respectively, while descriptions of the Tulloona fertiliser trial appear in Lester and Dowling (2001) and Lester et al. (2003). The Toowoomba (Wellcamp) tillage trial site had been sown to annual crops of winter wheat, with similar combinations of stubble management and tillage as Hermitage, but had only run for 9 consecutive seasons at the time of sampling, compared with the 35 years of predominantly annual wheat cropping at Hermitage (Thomas et al. 2003). The Warra rotation trial was designed to determine the impact of crop rotation on cotton productivity, and had been running for 10 years at the time of sampling. Treatments ranged from a cotton monoculture (with long bare fallows) through to an opportunity cropping treatment with a mix of winter and summer cereals, grain legumes, and cotton (Salmond and Hare 2002).

The trial sites examining the impact of breaking long fallows from summer sorghum to winter wheat using white French millet (Panicum miliaceum L.) were established on Vertosols in commercial fields near North Star in northern NSW and near Lundavra, north of Goondiwindi in southern Queensland. Both sites were fallowed after sorghum harvest in February 2004, and either left fallow or sown to millet in mid September 2004. Millet plots were either sprayed out at 6 weeks after planting or let grow through to maturity (about 12 weeks), after which all plots were sown to wheat on 18 May 2005. There were 6 replicate strips of each fallow treatment, with every alternate replicate sampled for soil biological assessments just prior to sowing the wheat crop.

\section{Soil collection and processing}

In the initial sample collections in 2002 and 2003, stratified soil samples were collected from the $0-0.05,0.05-0.15$, and (in some cases) the $0.15-0.30 \mathrm{~m}$ layers of the soil profile, with a number of representative samples collected from each plot (in the case of replicated field experiments) or at multiple sites (generally 5) distributed at random within a commercial field. While important differences in populations of soil biota can occur at greater depths in the soil profile (e.g. lesion nematodes; Peck et al. 1993), it was assumed that the most significant impacts of management on soil biota would be detected in these upper layers. Samples were collected from random positions around each sample point and included both row and inter-row locations. Samples were bulked for each sample point or replicate, homogenised, and then separated into subsamples for microbial or chemical analysis, or used in glasshouse bioassays.

Samples were generally collected from cropping sites immediately before or just after planting, in order to characterise the soil environment experienced by the establishing crops. The main sampling times were summer 2002-03 (after winter cropping and/or before summer sorghum planting) and winter 2003 (after summer cropping and before winter planting of wheat or chickpeas). Samples were collected at the same time in adjacent pastures or in undisturbed native vegetation. The Hermitage tillage trial was sampled twice (immediately after winter wheat in January 2003, and prior to sowing the next wheat crop in June 2003).

Samplings of the Tulloona fertiliser trial site and the Goondiwindi/North Star fallow length trials were undertaken at planting of the winter wheat crop (in May 2004 and May 2005, respectively), with an additional sampling undertaken shortly after harvest of the wheat at the Tulloona fertiliser trial in late 2004 (Table 1). Samples were collected from the $0-0.05,0.05-0.15$, and the $0.15-0.30 \mathrm{~m}$ layers of the soil profile at Tulloona, while a composite sample from the $0-0.15 \mathrm{~m}$ layer was collected from the fallow length trials.

\section{Quantification of microbial activity and diversity}

\section{Microbial biomass carbon}

Duplicate samples of soil $(10.0 \mathrm{~g}$ oven-dried equivalent at field collected moisture) were weighed into $50-\mathrm{mL}$ centrifuge tubes, adjusted using Type 1 water to $80 \%$ water filled porosity (Forster 1998), and microbial biomass carbon $(\mathrm{C})$ was determined using the microwave extraction method of Islam and Weil (1998).

The sample to be microwaved was covered with a lid containing a pin hole and exposed to $400 \mathrm{~J} / \mathrm{g}$ oven-dried equivalent soil, gently shaken, and exposed to another $400 \mathrm{~J} / \mathrm{g}$ oven-dried equivalent soil. Upon cooling, $25 \mathrm{~mL} 0.5 \mathrm{M} \mathrm{K}_{2} \mathrm{SO}_{4}$ was added to both the microwaved and nonmicrowaved soils, lids were replaced and samples were shaken lying down for $60 \mathrm{~min}$ on a flat bed orbital shaker at $140 \mathrm{rpm}$. The samples were centrifuged at $3000 \mathrm{G}$ for $10 \mathrm{~min}$, the supernatant was carefully decanted through fluted Whatman Number 40 filter paper into sample jars, and samples were then frozen at $-20^{\circ} \mathrm{C}$ prior to analyses. Upon thawing, samples were diluted 1 in 10 with Type 1 water and analysed for both inorganic $\mathrm{C}$ and total $\mathrm{C}$ by a Shimadzu Total Organic Carbon Analyser. Organic $\mathrm{C}$ was corrected as total minus inorganic $\mathrm{C}$.

Total microbial biomass $\mathrm{C}$ was determined by the formula:

$$
\mathrm{C}_{\mathrm{TMB}}=\mathrm{C}_{\mathrm{EXTMW}} / \mathrm{K}_{\mathrm{ME}}
$$

where $\mathrm{C}_{\mathrm{TMB}}$ is total microbial biomass $\mathrm{C}(\mathrm{mg} \mathrm{C} / \mathrm{L})$; $\mathrm{C}_{\text {EXTMw }}$ is net flush of $\mathrm{C}$ (difference between the extracted $\mathrm{C}$ in microwaved soil and the extracted $\mathrm{C}$ in field moist non-microwaved soil); and $\mathrm{K}_{\mathrm{ME}}$ is 0.213 (Islam and Weil 1998), the fraction of $\mathrm{C}_{\mathrm{TMB}}$ extracted by $0.5 \mathrm{M} \mathrm{K}_{2} \mathrm{SO}_{4}$

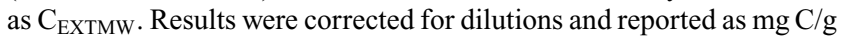
dry soil.

\section{Soil enzymes}

Estimates of general microbial activity were based on the ability of several enzymes (e.g. esterases, lipases, proteases), produced by bacteria or fungi, to cleave fluorescein diacetate (FDA), thereby releasing fluorescein, which can be measured spectrophotometrically or fluorometrically (Fontvieille et al. 1991).

Sieved $(<2 \mathrm{~mm})$ soil $500 \pm 5 \mathrm{mg}$ was weighed into a $115-\mathrm{mL}$ amber glass screw top jar. Twenty $\mathrm{mL}$ of sodium phosphate buffer $(0.1 \mathrm{M}$, $\mathrm{pH}$ 7.6) was added and the mixture shaken on a flat bed orbital shaker/incubator at $150 \mathrm{rpm}$ for $15 \mathrm{~min}$ at $23^{\circ} \mathrm{C}$. FDA stock $(100 \mu \mathrm{L}$ of $2000 \mathrm{~g} / \mathrm{L}$ solution of fluorescein diacetate in HPLC-grade acetone) was added to the soil suspension and shaken for a further $45 \pm 1 \mathrm{~min}$. Acetone $(20 \mathrm{~mL})$ was then added to terminate the reaction. The soil suspension was decanted into $50-\mathrm{mL}$ screw-cap centrifuge tubes and centrifuged at $25^{\circ} \mathrm{C}$ for $15 \mathrm{~min}$ at approximately $3000 \mathrm{G}$. Supernatant $(1 \mathrm{~mL})$ was added to a $10-\mathrm{mL}$ test tube and the sample diluted with Type 1 water (usually 1 in 5 dilution). Aliquots of the diluted sample $(250 \mu \mathrm{L})$ were placed into 96-well black plates and read along with an appropriate standard containing fluorescein $(0,0.3125,0.625,0.9375$, 1.25 , and $1.5625 \mathrm{mg}$ fluorescein/L water).

Plates were read by a Fluostar Galaxy fluorescent plate reader using $490 \mathrm{~nm}$ (excitation) and $520 \mathrm{~nm}$ (emission) filters. Results were corrected for dilutions and microbial activity expressed as mg sodium fluorescein/g dry soil. $45 \mathrm{~min}$.

The activity of $\beta$-glucosidase (one of a chain of enzymes that break down cellulose) was measured by blending $40 \mathrm{~g}$ dry weight equivalent of soil in $40 \mathrm{~mL}$ of $50 \mathrm{~mm}$ acetate buffer (pH 5.5) for $30 \mathrm{~s}$ and then shaking the slurry for $1 \mathrm{~h}$ at $26^{\circ} \mathrm{C}$ on an orbital shaker at $120 \mathrm{rpm}$. The slurry was then centrifuged at high speed for $5 \mathrm{~min}$ and filtered through a Whatman no. 1 filter paper. Sodium azide (Sigma) was added immediately to the soil extracts to give a final concentration of $0.04 \%$, and soil extracts were then stored at $4^{\circ} \mathrm{C}$ overnight.

Cold soil extract $(400 \mu \mathrm{L})$ was mixed with $400 \mu \mathrm{L}$ of cold enzyme substrate ( $p$-nitrophenyl $\beta$-D glucopyranoside; Sigma) prepared in 


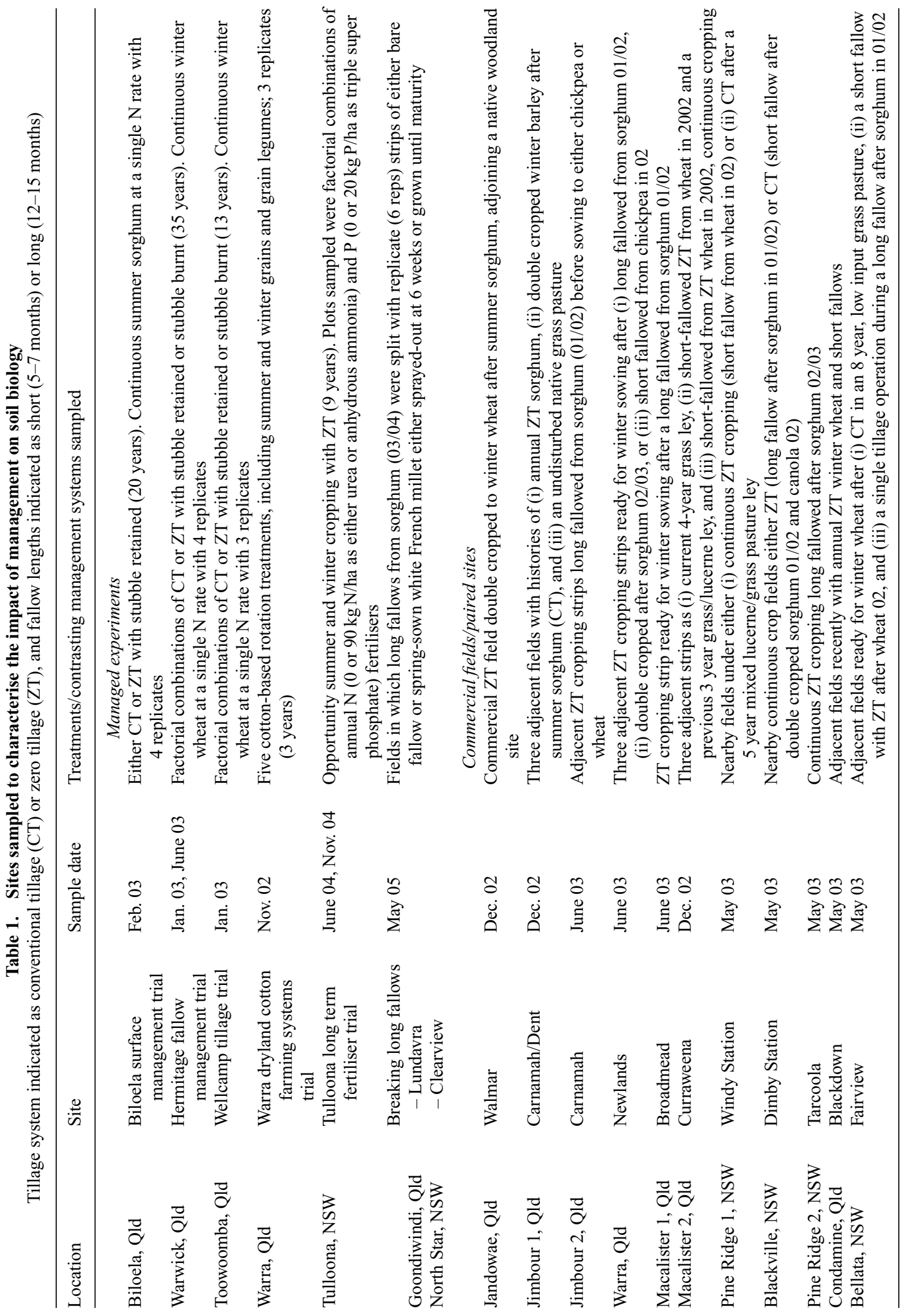


duplicate $1.5-\mathrm{mL}$ microtubes. This mixture was incubated for $24 \mathrm{~h}$ at $37^{\circ} \mathrm{C}$ in a water bath, after which the reaction was terminated using $400 \mu \mathrm{L}$ of cold $0.4 \mathrm{M} \mathrm{NaHCO}_{3}$. Following high-speed centrifugation, the absorbance of each sample and appropriate blanks (buffer, soil extract and substrate) was determined at $410 \mathrm{~nm}$. The concentration of $p$-nitrophenol (PNP) released during the assay was calculated from a calibration graph of the absorbance produced by $0-20 \mu \mathrm{g}$ of PNP in acetate buffer (Sigma).

\section{Nematode community analysis}

Studies of the nematode community in cereal-growing soils of Australia's northern grain belt have been published elsewhere (Stirling et al. 2004), so only 3 parameters derived from nematode community analyses were included in this paper. Root lesion nematode (predominantly Pratylenchus thornei, but also P. neglectus) was counted because it is widely distributed and is one of the most important soilborne pathogens limiting wheat yields in the study area (Thompson et al. 1995). Total numbers of free-living nematodes were estimated because they give an indication of the biological food resources that are available to the nematode community. The Nematode Channel Ratio $[N C R=B /(B+F)]$, calculated from the relative contribution of bacterial-feeding (B) and fungal-feeding nematodes (F) to total nematode abundance, was used to indicate whether decomposition processes in the soil were occurring predominantly through the bacterialbased energy channel or the slower, fungal-based channel. The ratio is constrained between values of 0 and 1 , with a value of 0 indicating that decomposition is totally fungal-mediated and 1 indicating total bacterial mediation (Yeates 2003).

Field moist soil $(200 \mathrm{~mL})$ was spread on a standard extraction tray (Whitehead and Hemming 1965) and after 2 days, nematodes were recovered by sieving twice on a $38 \mu \mathrm{m}$ sieve. Numbers of Pratylenchus and total free-living nematodes (FLN) were counted in fresh samples at a magnification of $40 \times$. Nematodes were then fixed in formalin-acetic acid and a sample of at least 100 randomly selected specimens was identified at a magnification of $400 \times$. Tylenchidae with small stylets and short or filiform tails were classified as fungivorous rather than as plant associates (Yeates et al. 1993) because they can be found in surface layers $(0-0.05 \mathrm{~m})$ above the root-zone, where they must survive on fungi associated with decomposing stubble.

\section{Extraction and quantification of soil DNA}

Soils were sieved (2-mm mesh) immediately after sampling and stored at $-20^{\circ} \mathrm{C}$ in plastic bags for up to 6 months. Prior to nucleic acid extraction, frozen soil samples were thawed and equilibrated for at least $24 \mathrm{~h}$ at $4{ }^{\circ} \mathrm{C}$. The soils were thoroughly mixed by shaking the bags for at least $2 \mathrm{~min}$, and three 200-mg aliquots of each soil sample were selected.

Each 200-mg aliquot of soil was mixed with $500 \mu \mathrm{L}$ of $0.1 \mathrm{~m}$ sodium phosphate buffer ( $\mathrm{pH} 8.0)$ in sterile $2-\mathrm{mL}$ screw-cap microcentrifuge tubes containing 0.3 and $0.8 \mathrm{~g}$ of $100 \mu \mathrm{m}$ and 1 -mm-diameter glass beads (Sigma, USA), respectively. Following centrifugation at $13000 \mathrm{rpm}$ for $2 \mathrm{~min}$ in an Eppendorf 5810R centrifuge (Eppendorf, Germany), the supernatant was discarded and $520 \mu \mathrm{L}$ of $0.1 \mathrm{~m}$ sodium phosphate buffer (pH 8.0) and $81 \mu \mathrm{L}$ of lysis buffer (1\% SDS, $0.5 \%$ Extran, 1\% PVP 40, $50 \mathrm{~mm}$ EDTA and $100 \mathrm{~mm}$ Tris) was added to the pelleted soil. Sample tubes were then processed for $30 \mathrm{~s}$ at $5.5 \mathrm{~m} / \mathrm{s}$ in a FastPrep FP120 bead-beater (Bio 101, Lajolla, CA) and subsequently centrifuged at $13000 \mathrm{rpm}$ for $5 \mathrm{~min}$. Approximately $600 \mu \mathrm{L}$ of supernatant was transferred into a sterile $2-\mathrm{mL}$ microtube, and mixed with $1 \mathrm{mg} / \mathrm{mL}$ (final concentration) of bovine serum albumin (Sigma, USA) to remove PCR-inhibitory phenolic compounds (e.g. tannins) (Thoss et al. 2002). The mixture was then chilled for $15 \mathrm{~min}$ on ice with $1 / 2$ volume of $7.5 \mathrm{M}$ ammonium acetate and centrifuged at $13000 \mathrm{rpm}$ for $5 \mathrm{~min}$. Approximately $710 \mu \mathrm{L}$ of supernatant was transferred to a fresh sterile $2-\mathrm{mL}$ microtube, mixed with $785 \mu \mathrm{L}$ precipitation solution $(20 \%$ polyethylenglycol 8000 and $2.5 \mathrm{M} \mathrm{NaCl})$ and incubated for $30-60 \mathrm{~min}$ at $37^{\circ} \mathrm{C}$ (Rowland and Nguyen 1993). DNA was pelleted by centrifugation at $13000 \mathrm{rpm}$ for $30 \mathrm{~min}$ at $4^{\circ} \mathrm{C}$. Pellets were washed twice with $70 \%$ ethanol, briefly dried under vacuum and resuspended in $80 \mu \mathrm{L}$ sterile DNAse-free milli-Q water (Invitrogen Life Technologies, USA).

Soil DNA was quantified using the PicoGreen dsDNA quantification kit (Molecular Probes, USA) according to the method described by Angersbach and Earp (2004). Briefly, $1 \mu \mathrm{L}$ of DNA was mixed with $199 \mu \mathrm{L}$ of diluted PicoGreen $(1: 200$ in TE buffer) in a black Greiner 96-well microtitre plate (Greiner Bio-one, Germany), and quantified for fluorescence in a Florostar fluorometer (BMG Labtech, $\mathrm{GmbH}$, Germany). DNA standards were prepared from bacteriophage DNA stocks (supplied with the PicoGreen kit). DNA yield was calculated as $\mu \mathrm{g}$ total DNA/g dry weight of extracted soil and was evaluated as a method for estimating the amount of microbial biomass (Arias et al. 2005).

Thirty soil samples representing contrasting treatments or management strategies from 6 locations (Warwick, Toowoomba, Jandowae, Macalister, Pine Ridge, and Condamine) (Table 1) were sent to the Root Disease Testing Service (South Australian Research and Development Institute, Adelaide, S. Aust.), where soil DNA was extracted and assessed for the presence of known root pathogens (Ophel Keller et al. 1999). These included cereal cyst nematode (Heterodera avenae), root lesion nematodes (Pratylenchus neglectus and P. thornei), and the pathogens responsible for take all (Gaeumannomyces graminis var. tritici), Rhizoctonia bare patch (Rhizoctonia solani $A G-8$ ), blackspot complex (Mycosphaerella pinodes, Phoma medicaginis var. pinodella, and Ascochyta pisi), and crown rot (Fusarium pseudograminearum).

\section{Fatty acid analysis of soil and microbial communities}

The same subset of 30 soil samples sent to the Root Disease Testing Service were analysed for both ester-linked and phospholipid-linked fatty acid methyl esters (EL-FAMEs and PL-FAMEs, respectively). Both techniques have been useful in detecting natural (e.g. between depths in a soil profile) or management-induced (e.g. between tillage systems) changes in soil fatty acid composition (Pankhurst et al. 2002). Although both techniques have been used to detect shifts in the composition of the soil microbial community (Cavigelli et al. 1995; Pankhurst et al. 2001), PL-FAMEs are considered more useful for this purpose as they are derived from cellular (living) soil biomass only, whereas EL-FAMEs are derived from both cellular and non-cellular (dead) soil biomass (Zelles 1999).

The procedures used for extraction and analysis of both EL-FAMEs and PL-FAMEs have been described in detail by Pankhurst et al. (2001), with analyses in this study done on 12-g subsamples of soil. Individual FAMEs were used as biomarkers for total bacteria (15:0, i15:0, a15:0,

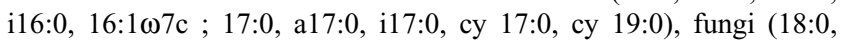
$18: 1 \omega 5 c, 18: 1 \omega 6 c, 18: 1 \omega 9 c, 18: 2 \omega 6 c, 18: 4 \omega 3 c$, Sum in Feature 8: 18:3 w3c/18:1 w8c, Sum in Feature 9: 18:1 w7c/18:1 w9t) and mycorrhizal fungi $(16: 1 \omega 5 \mathrm{c})$ and the ratio of fungal to bacterial fatty acids (Graham et al. 1995; Zak et al. 1996; Olsson 1999; Pankhurst et al. 2001).

\section{Soil chemical properties, total C, and C fractionation}

Samples for chemical analyses were oven dried $\left(40^{\circ} \mathrm{C}\right)$ and ground to $<0.125 \mathrm{~mm}$ for $\mathrm{C}$ analysis or $<2 \mathrm{~mm}$ for other chemical analyses. Most soil chemical analyses were undertaken using methods described by Rayment and Higginson (1992). Briefly, soil pH was determined in a $1: 5$, soil : water suspension, exchangeable cations were extracted with $1 \mathrm{M} \mathrm{NH}_{4} \mathrm{Cl}(\mathrm{pH} 7.0)$ and effective cation exchange capacity (ECEC) determined from the sum of exchangeable cations. Organic C was determined using the Walkley and Black procedure, while 
phosphorus (P) and zinc ( $\mathrm{Zn}$ ) were determined after extraction with $0.5 \mathrm{M} \mathrm{NaHCO}_{3}$ and DTPA, respectively.

Total $\mathrm{C}$ and $\mathrm{N}$ were determined by combustion in a Leco furnace. Various $\mathrm{C}$ fractions were determined by the amounts of $\mathrm{C}$ oxidised by $33 \mathrm{~mm}$ and $333 \mathrm{~mm} \mathrm{KMnO}_{4}$, as described in Blair et al. (1995) and used by Bell et al. (1999). The $\mathrm{C}$ oxidised by $33 \mathrm{~mm} \mathrm{KMnO}_{4}$ was termed Fraction $1 \mathrm{C}(\mathrm{C} 1)$ and the amount of $\mathrm{C}$ oxidised by $333 \mathrm{~mm} \mathrm{KMnO}_{4}$ was termed Fraction $3 \mathrm{C}(\mathrm{C} 3)$.

\section{Plant growth in glasshouse bioassays}

Glasshouse bioassays were done using soil samples from all sites (Table 1) with or without pre-treatment of steam pasteurisation $\left(60^{\circ} \mathrm{C}\right.$ for $60 \mathrm{~min}$ ), to assess potential biotic constraints in different regions, soil depths, and cropping systems. After pre-treatment, soils ( $750 \mathrm{~g}$ ovendried equivalent) were potted with levels of nutrients designed to provide luxury levels of chemical fertility. Nutrients were applied in solution at the following rates: $300 \mathrm{mg} \mathrm{N} / \mathrm{kg}$ as $\mathrm{CaNO}_{3}, 100 \mathrm{mg} \mathrm{P} / \mathrm{kg}$ as $\mathrm{NaH}_{2} \mathrm{PO}_{4}$, $10 \mathrm{mg} \mathrm{Zn} / \mathrm{kg}$ as $\mathrm{ZnCl}_{2}, 88 \mathrm{mg} \mathrm{K} / \mathrm{kg}$, and $36 \mathrm{mg} \mathrm{S} / \mathrm{kg}$ as $\mathrm{K}_{2} \mathrm{SO}_{4}$. Pots were placed on benches equipped with self-regulated watering systems and bioassay plants (sorghum cv. MR Buster, wheat cv. Hartog or chickpea cv. Jimbour) were grown for 8 weeks. At the end of the assay period plant tops were collected, dry weights determined and nutrients were analysed in composite samples. Roots were carefully recovered from soil by washing and root dry weight was determined.

\section{Statistical analyses}

Biological and chemical data from the survey sites in commercial fields are simply presented as means with associated standard errors. Data from long-term tillage and stubble management studies, fertiliser trials, and fallow length studies were analysed using analysis of variance techniques appropriate to the experimental design in each study. Statistical analyses were conducted on transformed data where appropriate.

Glasshouse pot trial results were also analysed using standard analysis of variance techniques for each crop species. Due to the layout of pasteurised and non-pasteurised pots within these glasshouse studies, analyses were done as a split-plot design with pasteurisation as the main plot and location/treatment as the subplots. Nesting techniques were used to accommodate the depth in the soil profile from which the various soil samples were collected at each location/treatment.

The relative pasteurisation response for each crop grown in each soil sample was calculated as the ratio of growth in non-pasteurised to growth in pasteurised soil, with growth determined as dry weight of biomass produced (tops and roots). As the wheat and chickpea assays were done at the same time and on the same soil samples, a pooled analysis of the wheat and chickpea relative pasteurisation response was employed to compare the pasteurisation responses of the 2 crop species.

\section{Results and discussion}

\section{Impact of management practices on soil biota}

The sites and land use comparisons sampled on the Vertosol soils covered a wide geographic region and a range of climate and management practice contrasts (e.g. from annual sorghum cropping in Biloela, through mixed summer and winter grain cropping in southern Queensland and northern NSW to predominantly wheat cropping in the southern Liverpool Plains). As the diversity of soil biota was likely to differ between climatic zones due to differences in temperatures and moisture availability, comparisons of soil biota under differing management practices (e.g. tillage systems) were initially constrained to within geographic regions. Consistency of response to these management options was then sought across the various sampling areas.

\section{Impact of continuous cropping}

The impact of cropping on soil biota and soil C status was only quantified at 2 sites in the central Darling Downs (Jandowae and Jimbour 1; Table 2), as contrasts between cropped and uncropped soils have been made in detail in other studies (e.g. Dalal and Mayer 1987; Pankhurst et al. 2000).

Cropping was shown to consistently reduce all measures of general microbial biomass or microbial activity, although a notable exception was evident from the PL-FAMEs at the Jandowae site (Table 2). Cropped soil contained only $30-50 \%$ of the microbial biomass and general microbial activity compared to the nearby uncropped reference sites, and this was consistent with similar declines in total $\mathrm{C}$ and $\mathrm{N}$. The PL-FAME result at Jandowae was unexpected and was in contrast to the results for the other biological parameters. This technique has been used successfully in other studies, and on similar soil types, to show that the microbial biomass is larger and more diverse in undisturbed soils than in soils used for agriculture (e.g. Pankhurst et al. 2000).

Despite the generally consistent declines with cropping, changes in specific components of the biological community (e.g. nematodes) were more variable. For example, while total free-living nematodes under continuous direct drill cropping had declined to much the same extent as general microbial activity at Jimbour 1, changes at Jandowae were much smaller. However, there were more relatively large omnivorous nematodes (Dorylaimida) at Jandowae than Jimbour 1, and so changes in nematode biomass rather than nematode numbers may have provided a better indication of the biological changes that occurred due to cropping. Other observations from the nematode assessments suggested an increasing fungal dominance of the microbial community under cropping (lower NCR values), although NCR trends with depth were different at the 2 locations. Interestingly, while Pratylenchus spp. were present only at the Jimbour 1 site, nematodes in this genus were present at similar populations in both cropped and uncropped sites $(0.31$ or 0.35 Pratylenchus spp./g soil, respectively). Pratylenchus thornei and $P$. neglectus are widespread on pastures in northern NSW (Stirling and Lodge 2005), but whether these important plant pathogens (Thompson et al. 1999) were naturally occurring in the undisturbed pasture at Jimbour 1 or were introduced via run off or erosion from adjoining crop lands, is currently unclear.

\section{Impact of tillage system and residue management}

We were able to assess the impacts of tillage systems and residue management on the replicated experiments at Biloela, Toowoomba, and Warwick (Table 1). Biloela was 


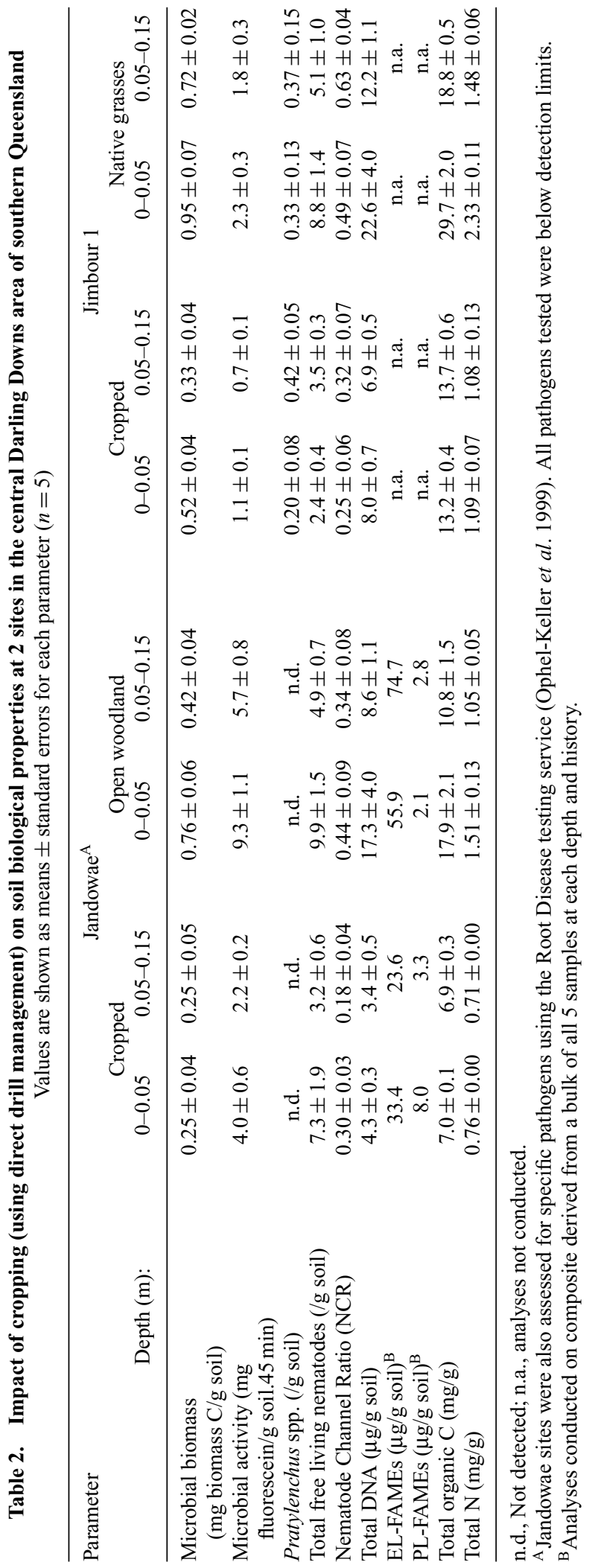


predominantly sown to summer sorghum, while the latter 2 sites were solely winter wheat. Adjacent commercial fields at Jimbour 1 and on the southern Liverpool Plains at Blackville provided similar contrasts (data not shown).

Data shown in Table 3 provide evidence that the combination of stubble retention and reduced tillage had a relatively small impact on most of the biological properties measured in these northern Vertosols. These results were not unexpected given the limited impact on soil organic C, and while consistent with reports from similar studies in lower rainfall subtropical regions (Dalal and Chan 2001), are in contrast to studies in cooler or wetter environments (e.g. Rovira 1994; Pankhurst et al. 2000). Significant effects were sometimes observed for microbial activity and numbers of free living nematodes, but effects on microbial biomass $\mathrm{C}$ were relatively small or non significant. Interestingly, the majority of the increased soil biota in direct-drill, stubbleretained systems occurred primarily in the top $0.05 \mathrm{~m}$ of the profile, with these localised increases sometimes reversed in the layer below, relative to conventionally tilled contrasts (e.g. microbial biomass and microbial activity at Warwick; Table 3).

There is evidence that stubble management and tillage system have an impact on the relative abundance of different functional groups in the microbial community. At the Biloela tillage study, low NCR values for the $0-0.05 \mathrm{~m}$ layer in the direct drill treatment $(0.19)$ reflect predominance of fungal feeding nematodes in that part of the soil profile, with the NCR value significantly lower than at the same depth under conventional tillage (0.39). In the $0.05-0.15 \mathrm{~m}$ layer, the significantly greater NCR value under direct drill $(0.50)$ indicated a better balance between fungi and bacteria, with this value not significantly different to NCR at that depth $(0.37)$ or in the $0-0.05 \mathrm{~m}$ layer under conventional tillage. Similar observations of increased fungal activity in surface layers of direct drill systems

Table 3. Impact of tillage system and stubble management on selected biological properties (microbial biomass $\mathrm{C}$, MBC, mg/g; microbial activity, MA, mg fluorescein/g.45 min; total free-living nematodes, FLN, per $\mathrm{g}$; total $\mathrm{C}$, $\mathrm{mg} / \mathrm{g}$ ) of soil in tillage trials at Toowoomba, Warwick (Hermitage) and Biloela

Values for 1.s.d. (0.05) are shown if applicable

\begin{tabular}{|c|c|c|c|c|c|c|c|c|c|c|c|c|}
\hline \multirow[t]{2}{*}{ Treatment } & \multicolumn{4}{|c|}{ Toowoomba } & \multicolumn{4}{|c|}{ Warwick $^{\mathrm{A}}$} & \multicolumn{4}{|c|}{ Biloela $^{\mathrm{B}}$} \\
\hline & $\mathrm{MBC}$ & MA & FLN & Total C & $\mathrm{MBC}$ & MA & FLN & Total C & $\mathrm{MBC}$ & MA & FLN & Total C \\
\hline \multicolumn{13}{|c|}{ Tillage } \\
\hline Conventional & 0.50 & 1.1 & 4.15 & 23.2 & 0.43 & 4.2 & 8.35 & 20.6 & 0.15 & 1.66 & 2.17 & 15.0 \\
\hline Direct drill & 0.51 & 1.3 & 3.50 & 23.6 & 0.48 & 3.9 & 6.10 & 21.5 & 0.15 & 1.95 & 1.50 & 15.1 \\
\hline 1.s.d. $(P=0.05)$ & n.s. & n.s. & n.s. & n.s. & 0.04 & n.s. & 1.97 & 0.7 & n.s. & 0.12 & n.s. & n.s. \\
\hline \multicolumn{13}{|c|}{ Stubble } \\
\hline Burnt & 0.50 & 1.0 & 3.26 & 23.3 & 0.40 & 3.3 & 4.69 & 20.2 & & & & \\
\hline Retained & 0.51 & 1.4 & 4.39 & 23.5 & 0.51 & 4.8 & 9.76 & 21.9 & & & & \\
\hline 1.s.d. $(P=0.05)$ & n.s. & 0.3 & n.s. & n.s. & 0.04 & 0.6 & 1.97 & 0.7 & & & & \\
\hline \multicolumn{13}{|c|}{ Depth } \\
\hline $0-0.05 \mathrm{~m}$ & 0.60 & 1.5 & 5.95 & 24.0 & 0.53 & 4.5 & 9.15 & 22.3 & 0.21 & 1.88 & 1.91 & 15.3 \\
\hline $0.05-0.15 \mathrm{~m}$ & 0.46 & 1.0 & 3.55 & 23.1 & 0.38 & 3.6 & 5.30 & 19.8 & 0.09 & 1.72 & 1.76 & 14.8 \\
\hline $0.15-0.3 \mathrm{~m}$ & 0.46 & 1.1 & 1.98 & 23.1 & n.d. & n.d. & n.d. & n.d. & n.a. & n.a. & n.a. & n.a. \\
\hline 1.s.d. $(P=0.05)$ & 0.08 & 0.4 & 1.77 & 0.5 & 0.04 & 0.4 & 2.15 & 0.8 & 0.04 & n.s. & n.s. & 0.3 \\
\hline \multicolumn{13}{|c|}{ Stubble tillage } \\
\hline Conv, burnt & 0.50 & 1.0 & 4.10 & 23.3 & 0.41 & 3.6 & 4.56 & 20.1 & & & & \\
\hline Conv, retain & 0.50 & 1.3 & 4.21 & 23.1 & 0.46 & 4.7 & 12.14 & 21.2 & & & & \\
\hline DD, burnt & 0.50 & 1.1 & 2.43 & 23.2 & 0.39 & 3.0 & 4.82 & 20.3 & & & & \\
\hline $\mathrm{DD}$, retain & 0.52 & 1.5 & 4.56 & 23.9 & 0.57 & 4.9 & 7.38 & 22.6 & & & & \\
\hline 1.s.d. $(P=0.05)$ & n.s. & n.s. & n.s. & n.s. & 0.06 & n.s. & 2.79 & n.s. & & & & \\
\hline \multicolumn{13}{|c|}{ Tillage depth } \\
\hline Conv, $0-0.05 \mathrm{~m}$ & 0.55 & 1.2 & 5.96 & 23.6 & 0.49 & 4.4 & 10.70 & 21.2 & 0.21 & 1.49 & 2.16 & 14.8 \\
\hline Conv, $0.05-0.15 \mathrm{~m}$ & 0.48 & 1.0 & 2.33 & 23.0 & 0.46 & 3.9 & 5.99 & 20.1 & 0.09 & 1.83 & 2.18 & 15.3 \\
\hline Conv, $0.15-0.30 \mathrm{~m}$ & 0.47 & 1.2 & 4.16 & 23.0 & n.d. & n.d. & n.d. & n.d. & n.d. & n.d. & n.d. & n.d. \\
\hline $\mathrm{DD}, 0-0.05 \mathrm{~m}$ & 0.64 & 1.8 & 5.93 & 24.3 & 0.57 & 4.7 & 7.60 & 23.3 & 0.21 & 2.27 & 1.66 & 15.8 \\
\hline $\mathrm{DD}, 0.05-15 \mathrm{~m}$ & 0.55 & 1.0 & 1.62 & 23.2 & 0.39 & 3.2 & 4.60 & 19.6 & 0.09 & 1.62 & 1.34 & 14.3 \\
\hline $\mathrm{DD}, 0.15-30 \mathrm{~m}$ & 0.55 & 1.0 & 2.94 & 23.1 & n.d. & n.d. & n.d. & n.d. & n.d. & n.d. & n.d. & n.d. \\
\hline 1.s.d. $(P=0.05)$ & n.s. & 0.5 & n.s. & n.s. & 0.05 & 0.67 & n.s. & 1.0 & n.s. & 0.24 & n.s. & 0.4 \\
\hline
\end{tabular}

n.s., Not significant; n.d., not detected; n.a., analyses not conducted.

${ }^{A}$ Combined analysis of samples collected in January and June.

${ }^{B}$ All treatments in Biloela trial were stubble retained. 
have been recorded elsewhere (e.g. Roper and Gupta 1995; McGhie et al. 1998).

The PL-FAME data for the conventional or direct-drill treatments in the Toowoomba study (both with stubble retained) also indicated differences in the relative abundance of the various functional groups in the soil biota in response to tillage (Fig. 1). Tillage had a significant impact on the relative abundance of fungal biomarkers in the top $0.05 \mathrm{~m}$ of the profile, with differences no longer evident in soil from the $0.15-0.30 \mathrm{~m}$ layer. However, in this case, signature fatty acids for fungi in the $0-0.05 \mathrm{~m}$ layer represented significantly greater proportions of total PL-FAMEs under conventional tillage than under direct drill, in direct contrast to the findings at Biloela and elsewhere in the literature (e.g. Roper and Gupta 1995; McGhie et al. 1998). Interestingly, NCR values for the same samples show no significant differences between tillage systems or depths, with values in the $0-0.05 \mathrm{~m}$ layer ( 0.46 and 0.44 for CT and ZT, respectively) similar to those in the $0.15-0.30 \mathrm{~m}$ layer below ( 0.37 and 0.53 for CT and ZT, respectively).

\section{Impact of fallow length and crop rotation}

In practical terms, fallow length and rotation will always be linked in cropping systems in the northern region, especially with the interchange between summer and winter cropping and the highly variable seasonal rainfall patterns (Webb et al. 1997). The key issue from a farming systems perspective is the composition and activity of the soil biota present at the time of crop establishment. This is illustrated by data from the Warra cropping systems trial (Fig. 2), assuming a planting opportunity in summer 2002-03. On this sampling occasion, fallow lengths ranged from 1 to 18 months and the previous crops were chickpea (1-month fallow), sorghum (6-month fallow), wheat (12-month fallow), and cotton (18-month fallow). Data for each parameter are expressed relative to those in the shortest (1 month) fallow to enable differing parameters to be presented simply and to enable trends in the different biological parameters to be compared across treatments. Data indicate a fairly consistent decline in all parameters with increasing length of fallow, but the contribution of the previous crop to this effect could not be determined from these data.

A limited number of sites offered opportunities to examine the effects of the single factors of fallow length or previous crop without confounding by other management issues. We did not consider instances where soil samples were collected at differing times during a fallow from the same trial (e.g. the Warwick tillage/stubble management trial), as each sampling time was characterised by marked differences in soil moisture conditions in the months preceding the sample collection. However, on-farm sites at Warra and nearby Macalister 1 (contrasting fallow lengths after a common previous crop, or contrasting previous crops with the same fallow length) and the Goondiwindi/North Star sites (opportunity millet cropping to break a long fallow) were suitable for these more detailed analyses.

The opportunity crop study sites at Goondiwindi and North Star (Table 1) were well suited to assessing the impact of long bare fallows on soil microbial activity. At both sites a long (15-month) fallow from summer sorghum (2003-04) to winter wheat (2005) was broken using spring-sown white French millet as either a very short brown manure (sprayed-out after 6 weeks) or a short duration grain crop (3.5 months duration). In these experiments (Table 4),

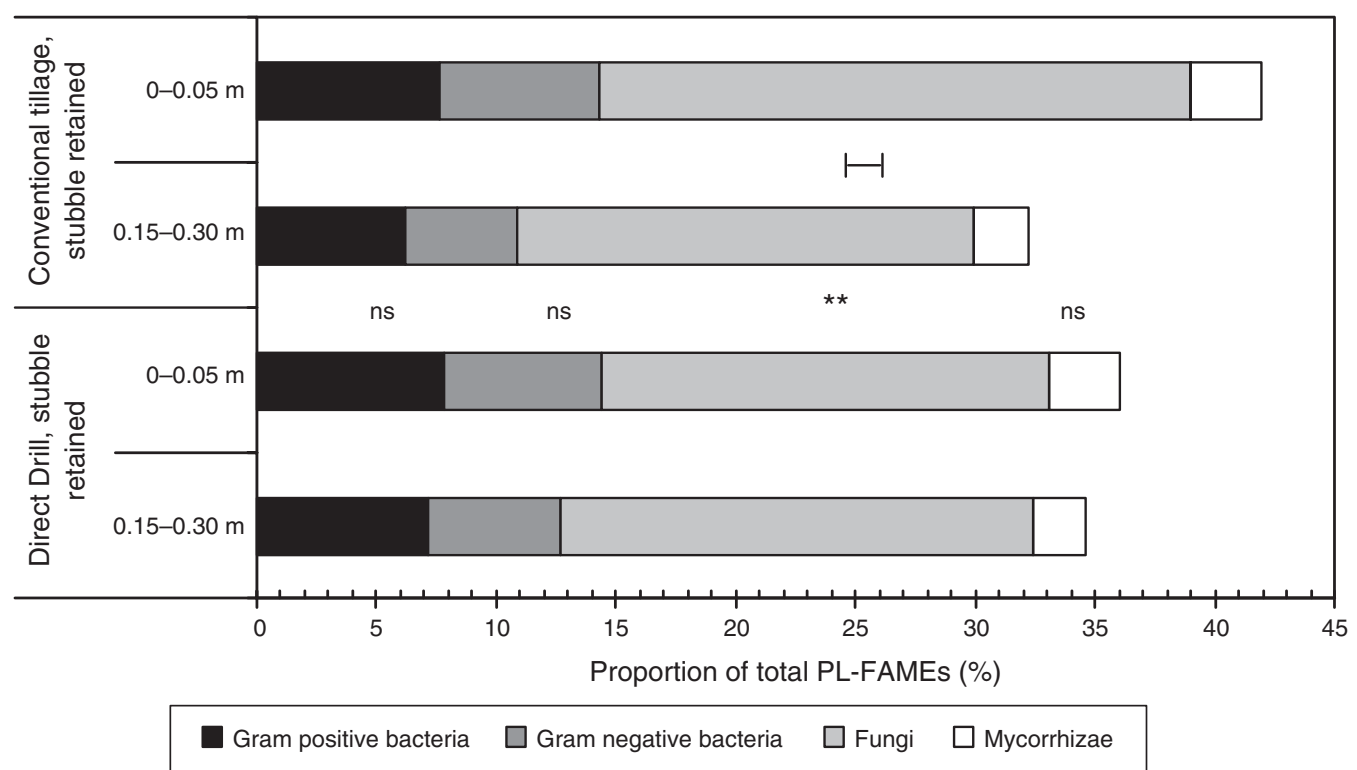

Fig. 1. Effect of tillage on microbial composition determined using PL-FAMEs in the Toowoomba tillage and stubble management trial. Horizontal bars indicate 1.s.d. $(P=0.05)$ values where appropriate. 


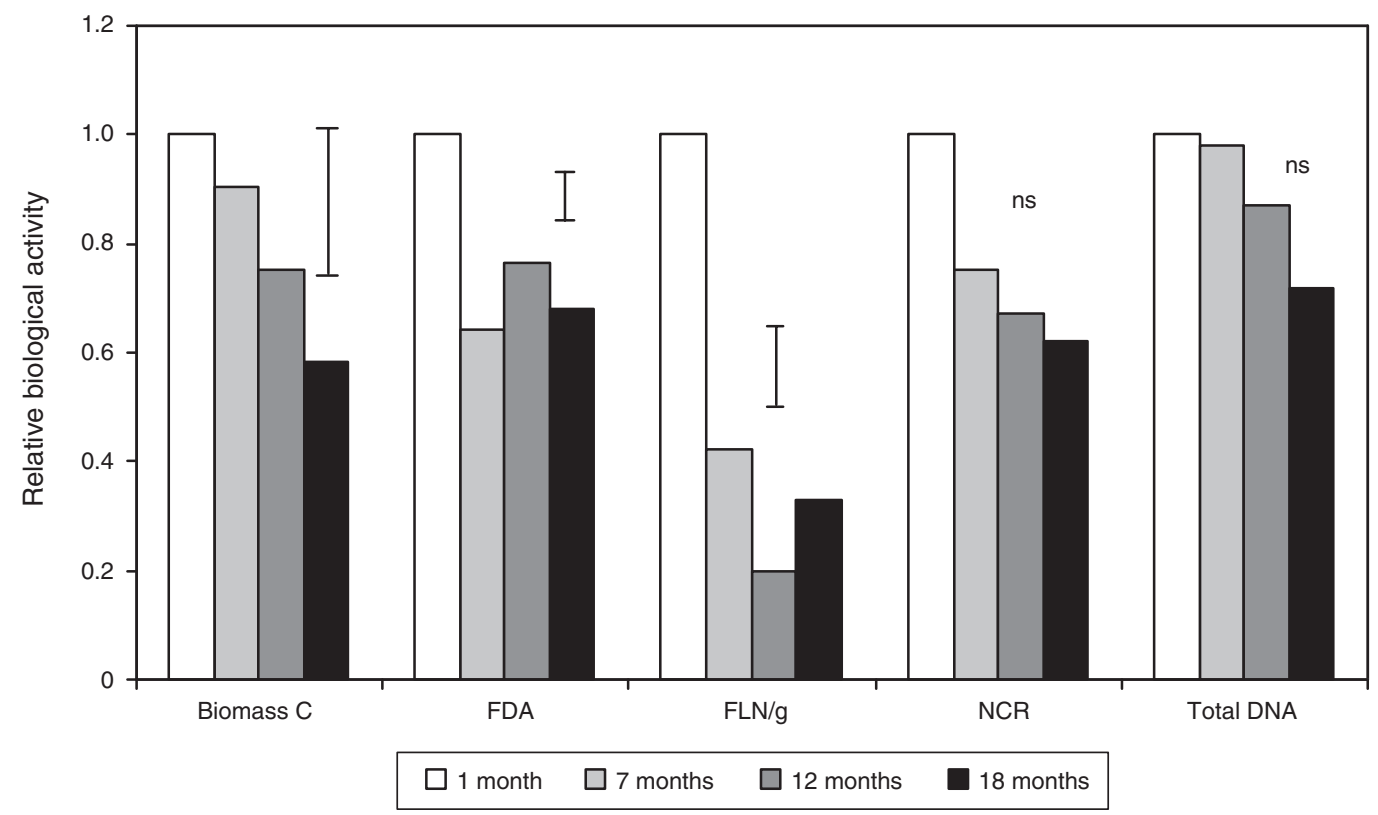

Fig. 2. Effects of fallow duration (months since previous crop) on selected soil biological properties in November 2002 at the Warra rotation trial. Data are expressed relative to values of the shortest fallow period, with the absolute values for the 1-month fallow treatment being $0.53 \mathrm{mg}$ biomass $\mathrm{C} / \mathrm{g}$ (Biomass C), $3.15 \mathrm{mg}$ fluorescein/g.45min (FDA), 6.31/g (FLN), 0.57 (NCR), and 17.94 ug/g (total DNA), respectively. Vertical bars indicate 1.s.d. $(P=0.05)$ values; n.s., not significant.

the long, bare fallow treatments had significantly lower populations of FLN and $\beta$-glucosidase activity at the time of wheat planting, compared to the full duration millet grain crop option during the fallow. The shorter duration, brown manure millet crop was generally not significantly different to the longer duration grain crop option. Data also suggest an increasing relative abundance of fungi in the microbial community as fallow length increased, as the NCR was 0.46 following the long bare fallow and 0.72 after grain millet. Again the shorter duration, brown manure was intermediate in impact.

The negative effects of long bare fallows on soil microbial communities were also observed in the commercial fields at Warra, with that site also providing a suggestion of poorer overall soil biology and lower soil C status 6 months after harvest of a chickpea crop than a wheat crop (data not shown). The generally lower crop residue levels after chickpea and the more rapid decomposition of those residues (Doughton and Holford 1997) may be a contributing factor to this phenomenon, but this conclusion needs to be confirmed.

The positive effects of breaking a long fallow with even a short duration crop like the spray-out millet option (Table 4) suggest that significant improvements in soil biological status can be achieved at a relatively low cost (both in terms of crop establishment and, more importantly, use of stored soil moisture). There may also be significant benefits in terms of soil cover (especially after sorghum grown in 1-m or $1.5-\mathrm{m}$ rows), which will improve rainfall infiltration and storage during the remainder of the summer fallow (Freebairn et al. 1997). The risks and potential benefits associated with water use/rainfall infiltration during traditional long fallows from summer to winter cropping are currently being examined using simulation modelling techniques. However, the increased numbers of root lesion nematodes (Pratylenchus spp.) in the millet crop treatments (Table 4) suggest choice of crop during these fallow periods will be critical so as not to maintain or exacerbate an existing soilborne pathogen.

\section{Impact of ley pastures}

The impact of pasture leys on soil microbial activity was assessed from sites in the southern Liverpool Plains (Pine Ridge 1), near Bellata in northern NSW and on the Darling Downs at Macalister 2. All sites were cropped prior to the ley phase and had been under pasture for $4-8$ years (Table 1). Samples were collected after tillage but just before sowing at Pine Ridge 1 and Bellata, but in the undisturbed grass ley at Macalister 2.

Pasture leys generally had a positive impact on soil $\mathrm{C}$ stores and microbial activity relative to adjoining fields in which the preceding crop had been winter wheat (Table 5), with the largest effects being measured in the deeper $(0.05-0.15 \mathrm{~m})$ samples. The magnitude of differences was 
Table 4. Effects of breaking a 16-month-long fallow from sorghum (2003-04) to wheat (June 2005) with white French millet grown as either a short-term, brown manure or through to crop maturity Data for $\beta$ glucosidase activity were transformed using $\ln (x+1)$ for analysis, with equivalent means shown in parentheses.

FLN, Free-living nematodes; NCR, Nematode Channel Ratio

\begin{tabular}{|c|c|c|c|c|}
\hline Effect & $\begin{array}{l}\text { Pratylenchus sp. } \\
\text { (/g soil) }\end{array}$ & FLN & NCR & $\begin{array}{c}\beta \text { glucosidase } \\
\text { activity } \\
(\mu \mathrm{g} \text { PNP/g soil.h) }\end{array}$ \\
\hline \multicolumn{5}{|c|}{ Location } \\
\hline Goondiwindi & 1.48 & 3.56 & 0.45 & $0.55(0.85)$ \\
\hline North Star & 1.09 & 4.44 & 0.73 & $0.12(0.14)$ \\
\hline 1.s.d. $(P=0.05)$ & 0.36 & n.s. & 0.10 & 0.33 \\
\hline \multicolumn{5}{|c|}{ Fallow management } \\
\hline Bare fallow & 0.78 & 0.61 & 0.46 & $0.12(0.13)$ \\
\hline $\begin{array}{l}\text { Short brown } \\
\text { manure millet }\end{array}$ & 1.11 & 5.09 & 0.59 & $0.41(0.56)$ \\
\hline Millet grain & 1.98 & 6.29 & 0.72 & $0.49(0.79)$ \\
\hline 1.s.d. $(P=0.05)$ & 0.42 & 2.27 & 0.16 & 0.22 \\
\hline \multicolumn{5}{|c|}{ Location $\times$ fallow management } \\
\hline $\begin{array}{l}\text { Goondiwindi } \\
\text { bare fallow }\end{array}$ & 0.64 & 0.58 & 0.39 & $0.21(0.23)$ \\
\hline $\begin{array}{l}\text { Goondiwindi } \\
\text { short brown } \\
\text { manure millet }\end{array}$ & 1.31 & 2.76 & 0.39 & $0.59(0.85)$ \\
\hline $\begin{array}{l}\text { Goondiwindi } \\
\text { grain millet }\end{array}$ & 2.51 & 7.33 & 0.57 & $0.89(1.47)$ \\
\hline $\begin{array}{l}\text { North Star } \\
\text { bare fallow }\end{array}$ & 0.92 & 0.65 & 0.52 & $0.03(0.03)$ \\
\hline $\begin{array}{l}\text { North Star } \\
\text { short brown } \\
\text { manure millet }\end{array}$ & 0.92 & 7.41 & 0.79 & $0.23(0.27)$ \\
\hline $\begin{array}{l}\text { North Star } \\
\text { bare grain } \\
\text { millet }\end{array}$ & 1.45 & 5.25 & 0.87 & $0.11(0.11)$ \\
\hline 1.s.d. $(P=0.05)$ & 0.51 & 2.96 & 0.19 & 0.31 \\
\hline
\end{tabular}

n.s., Not significant.

variable from site to site, no doubt confounded by whether the site had been tilled in preparation for a return to cropping (as in the Pine Ridge 1 and Bellata sites), the time since the pasture had been removed and the quality of the pasture itself. For example, the Bellata ley pasture was managed as a long-term, low-input grass pasture, whereas the Pine Ridge 1 pasture block was a higher input grass/lucerne pasture with carefully managed grazing. It should also be noted that the Pine Ridge 1 and Bellata cropped sites were sampled at the end of a short (6 month) fallow while the samples at Macalister 2 were taken shortly after wheat harvest (i.e. a fallow $<1$ month).

Samples collected in an adjacent cropping strip at Bellata which had been long fallowed out of sorghum (15-month fallows) showed 25-50\% lower levels of biological activity and soil $\mathrm{C}$ than the wheat field, and so the ley contrast was even more favourable (data not shown). Similarly, an adjacent cropping strip at Macalister 2 that had grown only a single wheat crop after a 3-year mixed grass/lucerne pasture ley generally showed soil $\mathrm{C}$ and biological properties intermediate between the continuous crop and pasture ley strips (data not shown), suggesting a decline in activity upon return to cropping despite the use of direct drill systems.

These observations support other studies that have shown generally positive soil biological responses to ley pastures, with observations noting positive impacts on soil $\mathrm{C}$ stores and overall microbial activity (e.g. Bell et al. 1997; Pankhurst et al. 2000; Dalal and Chan 2001). A more recent study by Stirling and Lodge (2005) has shown that grass pastures and mixed grass/legume swards generally produce higher levels of biological activity and more soil biota than pure legume pastures (e.g. lucerne), and while we did not sample any pure lucerne leys in this study the grass or mixed grass legume leys did show consistent biological benefits at all sites.

\section{Impact of artificial fertilisers}

The impact of artificial $\mathrm{N}$ and $\mathrm{P}$ fertilisers at rates consistent with optimum crop performance produced minimal impacts on general measures of soil biological activity or abundance (Table 6), either when sampled prior to planting or just after crop harvest. Like many other continuously cropped (direct-drill) sites in this study, biological activity was strongly stratified, with activity greatest near the surface and decreasing quite markedly with depth. The NCR suggested a reasonably well-balanced microbial community near the soil surface, with increased fungal dominance with increasing depth. Microbial activity, measured by degradation of fluorescein diacetate, more than doubled from the pre-planting sampling to post-harvest (Table 6), with all other measured biological parameters remaining unchanged except for populations of root lesion nematode (Pratylenchus spp.). The latter increased from an average of $1.0-19.2$ nematodes $/ \mathrm{g}$ soil in the top $0.30 \mathrm{~m}$ of the soil profile during the crop growing season, with highest populations occurring in the $0.15-0.30 \mathrm{~m}$ layer in both samplings (i.e. 1.9 and 42.4 nematodes/g soil in the pre-planting and post-harvest samplings, respectively). This increase in root lesion nematodes with depth is consistent with other measurements in these cropping systems (Peck et al. 1993; J. P. Thompson, unpublished data). Despite these high nematode populations, the mean wheat yield from the trial was $5000 \mathrm{~kg} / \mathrm{ha}$ at a grain protein concentration exceeding 14\% (D. J. Lester, unpublished data).

Although recent studies in southern NSW (Angus et al. 1999) showed that anhydrous ammonia had short-term negative effects on total microbial activity and selected groups of microorganisms (e.g. protozoa), longer term studies such as those by Biederbeck et al. (1996) have shown minimal deterioration of soil quality after 10 years' use of either ammonia or urea at rates $<90 \mathrm{~kg} \mathrm{~N} / \mathrm{ha}$. Given that 


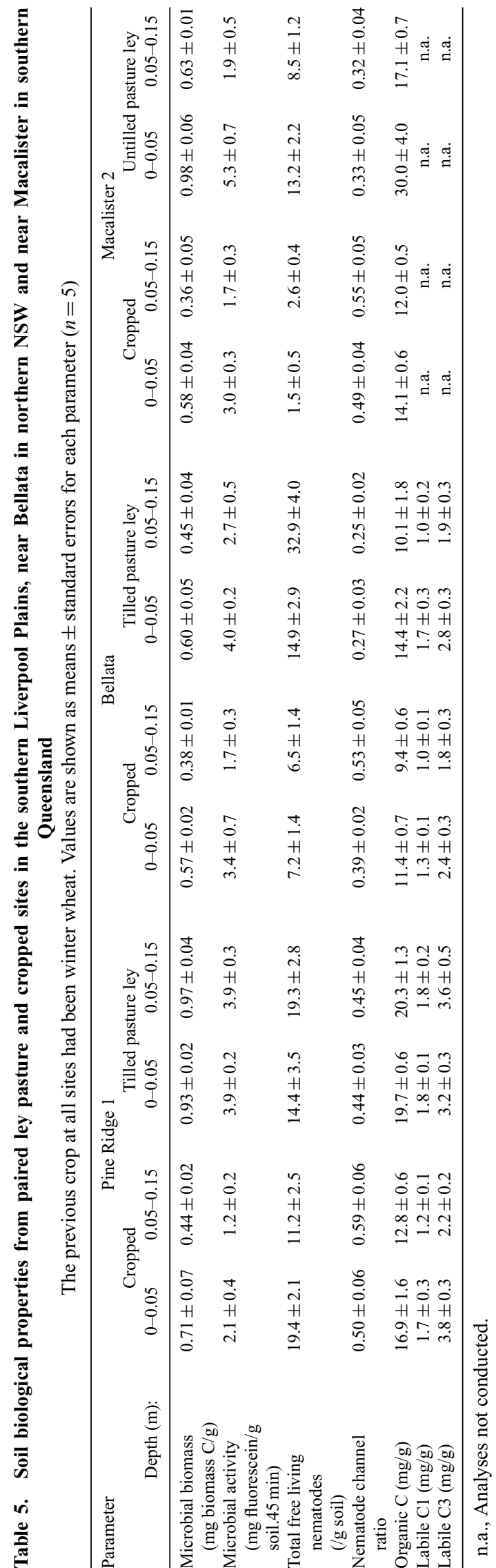


Table 6. Effects of nitrogen and phosphorus fertiliser applied at constant rates during the preceding 9 years on general microbial parameters (microbial biomass, $\mathrm{MBC}$, mg biomass $\mathrm{C} / \mathrm{g}$; microbial activity, MA, mg fluorescein/g soil. $45 \mathrm{~min}$; total free living nematodes, FLN, per $g$ soil) at Tulloona in northern NSW

Pre-planting and post-harvest samples were collected in June and November 2004, respectively. There were no significant interactions between sampling time and $\mathrm{N}$ or $\mathrm{P}$ fertiliser for any parameter

\begin{tabular}{|c|c|c|c|c|}
\hline & $\mathrm{MBC}$ & MA & FLN & $\mathrm{NCR}$ \\
\hline \multicolumn{5}{|c|}{ Sample time } \\
\hline Pre-planting & 0.31 & 1.16 & 3.1 & 0.43 \\
\hline Post-harvest & 0.32 & 2.92 & 3.0 & 0.44 \\
\hline 1.s.d. $(P=0.05)$ & n.s. & 0.44 & n.s. & n.s. \\
\hline \multicolumn{5}{|c|}{ Nitrogen } \\
\hline $0 \mathrm{~N}$ & 0.32 & 2.06 & 3.1 & 0.40 \\
\hline $90 \mathrm{~kg} \mathrm{~N}$ as $\mathrm{NH}_{3}$ & 0.30 & 1.91 & 3.0 & 0.44 \\
\hline $90 \mathrm{~kg} \mathrm{~N}$ as urea & 0.32 & 2.15 & 3.2 & 0.46 \\
\hline 1.s.d. $(P=0.05)$ & n.s. & n.s. & n.s. & n.s. \\
\hline \multicolumn{5}{|c|}{ Phosphorus } \\
\hline $0 \mathrm{~kg} P$ & 0.33 & 2.04 & 2.9 & 0.41 \\
\hline $20 \mathrm{~kg} \mathrm{P}$ & 0.30 & 2.04 & 3.3 & 0.45 \\
\hline 1.s.d. $(P=0.05)$ & n.s. & n.s. & n.s. & n.s. \\
\hline \multicolumn{5}{|c|}{ Depth } \\
\hline $0-0.05 \mathrm{~m}$ & 0.39 & 3.67 & 4.4 & 0.49 \\
\hline $0.05-0.15 \mathrm{~m}$ & 0.31 & 1.58 & 3.2 & 0.47 \\
\hline $0.15-0.3 \mathrm{~m}$ & 0.24 & 0.87 & 1.6 & 0.34 \\
\hline 1.s.d. $(P=0.05)$ & 0.04 & 0.21 & 0.7 & 0.06 \\
\hline
\end{tabular}

n.s., Not significant.

$\mathrm{N}$ fertiliser treatments were applied c. 2 months prior to planting (and the first soil sampling), data in Table 6 would seem to indicate that any short-term negative impacts on most of the microbial community had already dissipated. However, a more detailed analysis of the free-living nematode community showed that populations of Dorylaimida were significantly reduced when either $\mathrm{N}$ (both as urea or anhydrous ammonia) or P (applied as triple super phosphate at planting) fertilisers were used. The effect on populations of Dorylaimellus, the most common dorylaimid genus at the site, was apparent at planting and was still evident in the post-harvest sampling (Table 7), suggesting that the treatment-related stress was more than a temporary effect that occurred when fertilisers were applied. This group of nematodes is particularly sensitive to various sources of N (Tenuta and Ferris 2004), and populations are often reduced by N and P fertilisers (Yeates and King 1997; Sarathchandra et al. 2001), and so the negative effects of both $\mathrm{N}$ and $\mathrm{P}$ were not unexpected. It is possible that the response of dorylaimid nematodes was due to fertiliserinduced changes in the availability of their food sources, and if this could be confirmed and their feeding habits better understood, these nematodes may eventually prove to be useful biological indicators.
Table 7. Abundance of Dorylaimellus sp. (the most common omnivorous nematode) in different depths of the soil profile at Tulloona as affected by annual applications of $N$ and $P$ fertiliser

\begin{tabular}{|c|c|c|c|}
\hline \multirow[b]{2}{*}{ Depth (m): } & \multicolumn{3}{|c|}{ Numbers of Dorylaimellus sp. $/ 200 \mathrm{~mL}$ soil ${ }^{\mathrm{A}}$} \\
\hline & $0-0.05$ & $0.05-0.15$ & $0.15-0.3$ \\
\hline \multicolumn{4}{|c|}{ Effect of $N$ fertiliser } \\
\hline $0 \mathrm{~kg} \mathrm{~N} / \mathrm{ha}$ & $0.414(0.5)$ & $3.138(22.1)$ & $3.179(23.0)$ \\
\hline $90 \mathrm{~kg} \mathrm{~N} / \mathrm{ha}$ as $\mathrm{NH}_{3}$ & $0.134(0.1)$ & $1.546(3.7)$ & $2.114(7.3)$ \\
\hline $90 \mathrm{~kg} \mathrm{~N} / \mathrm{ha}$ as urea & $0.573(0.8)$ & $1.571(3.8)$ & $1.625(4.1)$ \\
\hline 1.s.d. $(P=0.05)$ & \multicolumn{3}{|c|}{0.677} \\
\hline \multicolumn{4}{|c|}{ Effect of $P$ fertiliser } \\
\hline $0 \mathrm{~kg} \mathrm{P} / \mathrm{ha}$ & $0.472(0.6)$ & $2.869(16.6)$ & $3.069(20.5)$ \\
\hline $20 \mathrm{~kg} \mathrm{P} / \mathrm{ha}$ & $0.276(0.3)$ & $1.300(2.7)$ & $1.543(3.7)$ \\
\hline 1.s.d. $(P=0.05)$ & \multicolumn{3}{|c|}{0.553} \\
\hline
\end{tabular}

\section{Plant growth differentials in the glasshouse (including biocidal treatments)}

Plant growth in glasshouse studies provided a means of studying the interaction between soil physical properties, soil biota, plant roots, and above ground biomass production, in the absence of other constraints such as inadequate moisture or suboptimal levels of essential nutrients. In all studies there were consistent effects on plant growth at the depth in the profile from which the soil was collected, with growth always better when plants were grown in soil from the top $0.05 \mathrm{~m}$. In non-pasteurised soil, the average growth advantage for plants grown in soil from the top $0.05 \mathrm{~m}$ layer was smaller for chickpea $(11 \%)$ than wheat or sorghum (41 and 36\%, respectively). Pasteurisation reduced this growth differential in wheat to only $13 \%$ (although this varied from site to site), but had no real effect for sorghum or chickpea (28 and $11 \%$, respectively). The reasons for this depth effect are not known, but as growth differences were evident in both pasteurised and non-pasteurised soil it was assumed that a component of this effect was due to differences in soil physical properties rather than to differences in soil biota.

The addition of soil pasteurisation as a factor in these studies allowed an assessment of the relative constraint imposed by soil biota in all situations. In order to investigate the severity of these constraints on each of the target crop species (wheat, sorghum, and chickpea), the growth of each crop species in each soil layer from each location or management system was expressed relative to growth in the pasteurised soil from that same location, profile layer and management system. The wheat and chickpea bioassays were conducted on the same soils in winter and spring 2003, so a combined analysis of data was undertaken. The soil collection and bioassays for sorghum were conducted 6 months prior 
to those of wheat and chickpeas, so data were analysed separately for that crop.

Relative shoot growth of plants grown in the soils from the various commercial fields shown in Table 1 highlighted significantly different pasteurisation responses with crop species, and in the case of wheat, a significant interaction with soil depth. Chickpea showed small but statistically significant responses to pasteurisation, with shoot dry matter grown in soil from the $0-0.05$ and $0.05-0.15 \mathrm{~m}$ zones averaging 85 and $84 \%$ of that in the same soil with pasteurisation. In contrast, sorghum and wheat showed much larger responses to pasteurisation. In unpasteurised soil, sorghum shoot dry matter was only $52 \%(0-0.05 \mathrm{~m})$ and $50 \%(0.05-0.15 \mathrm{~m})$ and wheat shoot dry matter $75 \%(0-0.05 \mathrm{~m})$ and $53 \%(0.05-0.15 \mathrm{~m})$ of that from plants grown in the same soil with pasteurisation. Similar species differences were recorded for root dry matter, although root growth was slightly less responsive than shoot growth to soil pasteurisation in all species (data not shown).

The above data clearly illustrate that all crop species do not grow as well in field soil as in steam pasteurised soil. The largest responses to pasteurisation occurred with sorghum and wheat, the latter especially in the $0.05-0.15 \mathrm{~m}$ layer of the profile. Similar species effects were observed in the long-term tillage trials at Warwick, Wellcamp, and Biloela, although the effects of depth varied. For example, the wheat-chickpea comparison in Warwick soil showed no significant effects of depth, but strong species differences [i.e. relative shoot growth of chickpea (114\%) was much greater than that of wheat $(38 \%)]$. The strong growth limitations in wheat but not chickpea are almost certainly related to the predominantly wheat monoculture in this trial for the last 35 years (Thomas et al. 2003). This result suggests that soil-borne pathogens are a constraint to wheat production at this site, and that the natural suppression seen to develop for some of the major wheat pathogens under continuous direct-drill wheat in southern cereal systems (Roget et al. 1999) may not develop for the biota involved in the growth response at Warwick, or may be inhibited by climatic or edaphic effects.

Interestingly, strong pasteurisation responses were recorded in sorghum in both the Warwick and Toowoomba tillage and residue management trials, despite sorghum not being grown at Warwick for at least 35 years and Toowoomba for at least 15 years. At Warwick, constraints were only significant in soil from the $0.05-0.15 \mathrm{~m}$ layer (relative shoot growth of $62 \%$ ) but at Toowoomba, constraints were evident in soil from all depths and were greatest in the deepest layer sampled (i.e. relative shoot growth of 48,62 , and $37 \%$ for the $0-0.05,0.05-0.15$, and $0.15-0.3 \mathrm{~m}$ layers, respectively).

Collectively, these data suggest widespread biotic constraints across the Vertosols of the northern grains region, with these constraints having the biggest impact on the important grain crops (wheat and sorghum) rather than on chickpeas. Known pathogens were evident in some locations (e.g. lesion nematode in the cropped sites at Jimbour 1 and 2 and Goondiwindi/North Star; Tables 2 and 4) but not in others, while there was evidence of crown rot infection in wheat plants grown in non-pasteurised soil from some sites (e.g. Pine Ridge 1 and 2 and Blackville; Table 1). However the general nature of the pasteurisation response across all cropped sites suggests major known pathogens were not the prime cause of the growth constraint.

The relatively few uncropped sites sampled in this study did not allow a thorough examination of the hypothesis that these constraints have developed as a result of cropping. However, the sorghum pasteurisation response was significantly less in the uncropped Jimbour 1 (grass pasture) and Jandowae (open woodland) soils than in cropped soil from the adjacent fields. Relative tops dry matter production on the uncropped soils from Jimbour 1 and Jandowae was 77 and $70 \%$ of that in equivalent pasteurised soil, whereas it was only 43 and $41 \%$ in the soil from cropped fields.

Data from 3 ley pasture sites suggested that ley pastures were not a management option that would consistently minimise these constraints, as the relative growth response in crop and pasture soils did not differ significantly at 2 sites (Fig. 3). Similarly, there were no obvious relationships between tillage system or fallow length and the magnitude of these constraints.

\section{Relationships between various biological parameters}

We used a number of accepted techniques in this study to quantify the overall levels of biological activity of soils in response to management, with some of those techniques seemingly more sensitive to management than others (Tables 2, 3, and 4). However, with the exception of strong correlations between the various measures of total and labile organic carbon, the correlations between various biological and biochemical measurements were relatively poor. Data are presented (Table 8) for the soils collected in winter 2003 and used in the wheat and chickpea bioassays, while similarly poor correlations exist for soils collected in late 2002 and early 2003 and used in the sorghum bioassays (data not shown). Within local regions, or in some cases only within similar land uses within a region, correlations between methods were quite strong [e.g. in the Jimbour 1 sites described in Table 1, microbial activity was strongly correlated to microbial biomass $\mathrm{C}$ across the 3 management histories $(r=0.75, n=30)$ ]. However these relationships varied considerably in broader terms when considered across land management systems, but particularly across geographic areas within the region. As an example, the correlation between microbial activity and microbial biomass $\mathrm{C}$ was much weaker at nearby Jandowae, even excluding the uncropped site, and there was more than 3 times the microbial activity per unit of biomass $\mathrm{C}$ (data not shown). This variation highlights the difficulties involved in using particular parameters or groups of parameters 


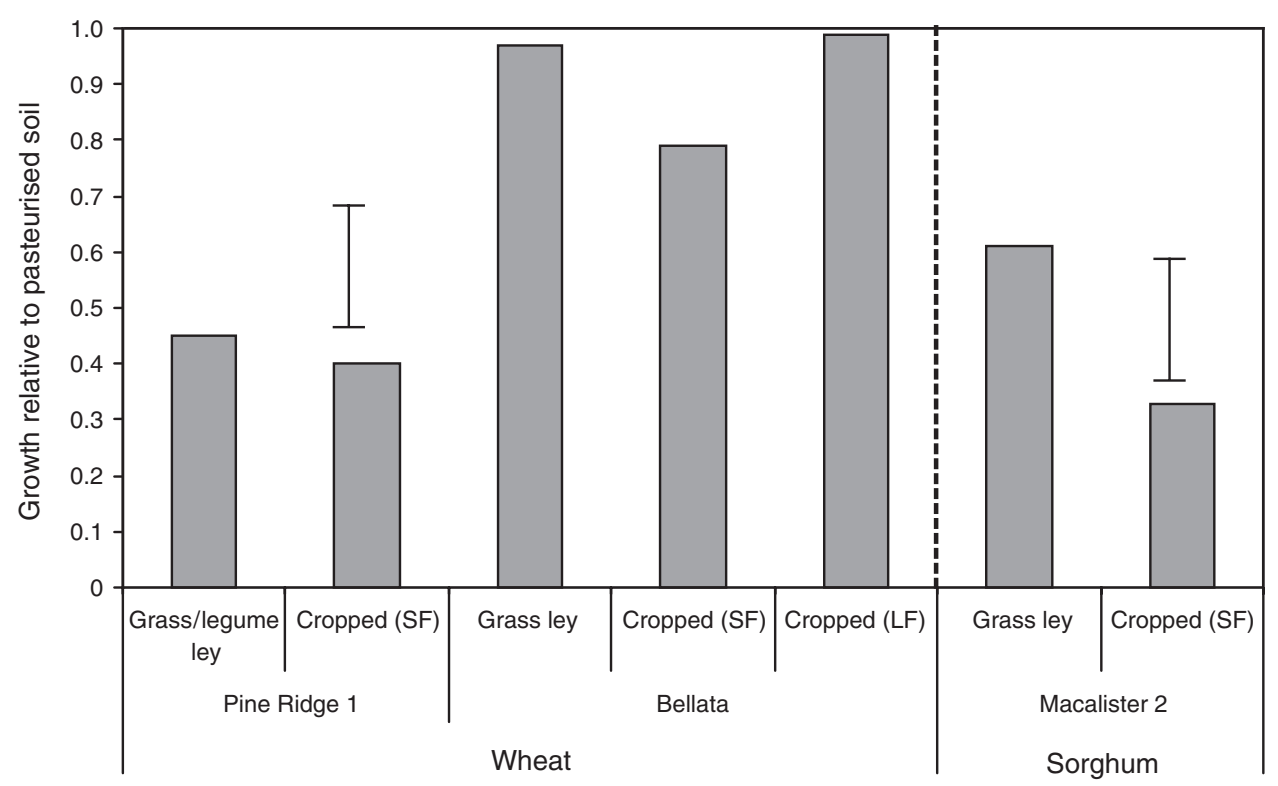

Fig. 3. Growth response to soil pasteurisation by wheat and sorghum in soils either continuously cropped (SF, short fallow or LF, long fallow) or under pasture leys. The dashed vertical line separates the data from the wheat and sorghum assays. Vertical bars indicate 1.s.d. $(P=0.05)$ values where appropriate.

Table 8. Correlation matrix between various measures of soil biota and soil $C$ and the relative shoot dry matter production by wheat in the glasshouse bioassays $(n=128)$

Measures of biota include abundance of root lesion (Pratylenchus/g) and total free-living (FLN) nematodes, rate of hydrolysis of fluorescein diacetate (FDA), microbial biomass C (biomass C), total DNA and Nematode Channel Ratio (NCR); soil C measures included total organic $\mathrm{C}$ and labile $\mathrm{C}$ oxidised by 33 and $333 \mathrm{~mm} \mathrm{KMnO}_{4}(\mathrm{C} 1$ and $\mathrm{C} 3$, respectively). Shoot dry matter production is relative to that of plants grown in pasteurised soil

\begin{tabular}{|c|c|c|c|c|c|c|c|c|c|c|}
\hline & $\begin{array}{l}\text { Shoot } \\
\text { response }\end{array}$ & $\begin{array}{l}\text { Pratylenchus } \\
\text { per g }\end{array}$ & $\mathrm{FLN} / \mathrm{g}$ & FDA & $\begin{array}{c}\text { Biomass } \\
\mathrm{C}\end{array}$ & $\begin{array}{l}\text { Total } \\
\text { DNA }\end{array}$ & $\underset{\mathrm{C}}{\text { Organic }}$ & $\mathrm{C} 1$ & $\mathrm{C} 3$ & NCR \\
\hline Shoot response & 1.00 & & & & & & & & & \\
\hline Pratylenchus/g & -0.27 & 1.00 & & & & & & & & \\
\hline $\mathrm{FLN} / \mathrm{g}$ & 0.26 & -0.16 & 1.00 & & & & & & & \\
\hline FDA & 0.02 & -0.08 & 0.24 & 1.00 & & & & & & \\
\hline Biomass C & -0.02 & 0.07 & 0.38 & 0.44 & 1.00 & & & & & \\
\hline Total DNA & -0.01 & 0.18 & 0.16 & 0.06 & 0.72 & 1.00 & & & & \\
\hline Organic $\mathrm{C}$ & -0.43 & 0.10 & 0.05 & 0.68 & 0.38 & 0.01 & 1.00 & & & \\
\hline $\mathrm{C} 1$ & -0.28 & -0.01 & 0.15 & 0.76 & 0.34 & -0.08 & 0.96 & 1.00 & & \\
\hline $\mathrm{C} 3$ & -0.25 & 0.00 & 0.18 & 0.70 & 0.37 & -0.06 & 0.88 & 0.93 & 1.00 & \\
\hline NCR & -0.05 & 0.46 & -0.28 & -0.19 & 0.11 & 0.25 & -0.15 & -0.21 & -0.13 & 1.00 \\
\hline
\end{tabular}

to monitor the biology that is associated with soil 'health' in cropping systems.

DNA analyses were included in this study because of their potential to provide information on soil biology that is not available using traditional techniques. In these studies there were a number of examples of total DNA yield indicating similar treatment responses as other biological measurements (Table 2). For example, higher DNA concentrations were found in uncropped soils in both Jandowae and Jimbour 1, as were measurements for total organic $\mathrm{C}$ and microbial activity (FDA). This trend was also reflected between soil depths. When all soils used in glasshouse assays were considered, a strong positive correlation was recorded between total DNA and total organic $\mathrm{C}$ measurements $(r=0.72)$, as has been observed by other researchers (Zhou et al. 1996; Johnson et al. 2003). More detailed analysis of the DNA samples collected from these soils may provide a more thorough understanding of microbial diversity between regions and management systems.

One problem with our results is that none of the parameters measured correlated in any way (positively or negatively) with growth constraints in glasshouse studies (Table 8), with the possible exception of a negative correlation between the growth response to pasteurisation and soil organic C $(r=-0.43)$. This suggests that if biological measurements are to be useful to landholders interested in 
maximising crop production, additional monitoring tools will have to be developed or our understanding of the interaction between crop roots and the soil biology will need to improve.

\section{General discussion}

This study has shown that there is considerable variation in the quantity, activity, and constituents of the soil biological community in Vertosol soils of the northern grains region, and that land management (cropping or pastures, tillage system, and fallowing strategy in particular) is a major factor contributing to this variation. The work has also suggested that there are widespread biotic constraints in soils of the region that can limit growth of the predominant grain crops (wheat and sorghum) under controlled conditions in the glasshouse. These growth limitations can be quite substantial and do not appear to be related to the presence of any known pathogen. Additionally, these constraints do not appear to be consistently affected by management, other than a suggestion that effects are greater in cropped soils. This is contrary to the findings for major diseases like crown rot (Wildermuth et al. 1997), take-all (Rovira 1990), Pythium root rot (Pankhurst et al. 1995), and Rhizoctonia bare patch (Neate 1987).

Rotation with non-host crop or pasture species remains an integral part of managing soil-borne pathogens (Gardner et al. 1998), but the choice of rotation crop is critical. In the northern region, chickpea has been a preferred grain legume rotation for breaking disease cycles and rejuvenating soil $\mathrm{N}$ but has been found to also host lesion nematodes (Wildermuth et al. 1997). The apparent biotic constraints to both wheat and sorghum shown in this study suggest a strong need for a viable and well-adapted break-crop to fill a similar role to that of canola in southern production regions, where significant advantages over traditional grain legume and other break crops have been recorded (Kirkegaard et al. 1997, 2003).

The extent to which soil biota are constraining productivity of sorghum and wheat crops in the field across the northern region is not known, although losses from lesion nematodes and crown rot in wheat have been estimated at $\$ 56 \mathrm{M}$ per annum (Brennan and Murray 1998). This study suggests that the impact of soil-borne pathogens may actually be considerably higher, although the contrasting moisture conditions and root systems in field grown $v$. glasshouse-grown plants may prove a moderating impact on the constraints.

The measures of soil biota and the glasshouse assays in this work have only been made in soil from the top $0.15-0.30 \mathrm{~m}$ of the profile, and the extent to which constraints in the soil surface are representative of similar constraints in deeper layers is not known. Peck et al. (1993) have clearly demonstrated that lesion nematode populations can be highest at depths of $0.60 \mathrm{~m}$ or greater, with the distribution of plant-parasitic nematodes presumably reflecting the distribution of the crop root systems and more stable soil moisture conditions. The data from this study showing that relative growth constraints were often greater with increasing depth (wheat grown in soil from all commercial fields and from the Toowoomba tillage trial) suggest that the detrimental biota in this study may also be more common at depth.

Our measurements were made in composite soil samples collected at random (i.e. both row and inter-row positions) within the field. However, Stewart et al. (1999) have shown that in the red duplex soils of southern Australia, up to $80 \%$ of plant root systems under direct drill are located in or closely associated with macropores. While this figure may not be as high in cracking and self-mulching Vertosols, the same principles are likely to apply. Pankhurst et al. (2002) have shown that the microbial community associated with these macropores was completely different from that normally present in the bulk soil. As a result, re-colonisation of macropores by developing root systems of the next crop in a rotation will mean that roots are interacting with biota that may be quite different to those measured in the bulk soil used in this study. This is therefore an area that requires further examination, particularly as increasingly popular wide row spacings (e.g. single and double skip row plantings in sorghum and cotton and $45-50 \mathrm{~cm}$ row spacings in wheat) in response to dry seasonal conditions mean increasing heterogeneity of root distribution in the soil profile (Routley et al. 2003; Broad and Hammer 2004; M. J. Bell and J. Doughton, unpublished data).

This project used a number of techniques to quantify components of soil biota or biological activity in Vertosols in the northern cropping region, with the various measurement techniques either quantifying one component of the soil biota in detail (e.g. nematodes) or making a more general measurement of the microbial community (PL-FAMEs, microbial biomass C) or microbially mediated enzyme activity ( $\beta$-glucosidase or FDA). Some other techniques used (labile C, EL-FAMEs, and total DNA) are known to be unable to discriminate between living and dead biota, or between soil biota and material from plant roots and residues (e.g. Zelles 1999). It is therefore not surprising that there was no evidence of strong correlations between different measurements on the same soil samples (Table 8). The fact that individual measurements were sometimes unable to detect changes in response to land management (Tables $6 v$. 7), or provided conflicting results when assessing a management impact (e.g. contrasting tillage effects at Biloela and Toowoomba; text and Fig. 1) suggests that several parameters must be measured to obtain a realistic assessment of the soil biological status. The consistent correlations between total organic $\mathrm{C}$ or labile $\mathrm{C}$ and many of the soil biological parameters at most sites suggests these parameters should always be included in any soil biological assessment. 
Regardless of the methods used to assess the soil biology, our results indicated that the biological status of grain-growing soils in northern Australia is poor. Microbial activity in cropped soils ranged from 0.02 to $0.09 \mu \mathrm{g}$ fluorescein $/ \mathrm{g}$ soil.min, whereas soil below the $0-0.05 \mathrm{~m}$ layer often had fewer than 5 free-living nematodes $/ \mathrm{g}$ soil (Tables 2, 3, and 5). In both cases, these values are many orders of magnitude lower than values obtained for soils under other land uses in northern Australia (Stirling et al. 2001; Pankhurst et al. 2005; Stirling and Lodge 2005). It is therefore not surprising that our results showed that changes in management (e.g. reduced tillage, retention of crop residues) had little impact on the soil biota. The main factors limiting the biology in this environment are long fallows that limit cropping intensity (caused by variability in annual rainfall or alternating summer and winter cropping) and inputs of organic matter that are often less than that required to maintain a neutral soil $\mathrm{C}$ budget (estimated at $2 \mathrm{t}$ crop residue $\mathrm{C} /$ ha.year in continuous wheat cropping at Warra by Dalal et al. 1994, 1995). Although these levels of $\mathrm{C}$ inputs may be achieved in the more reliable southern and eastern parts of the cropping region where winter cereal yields of $5 \mathrm{t} / \mathrm{ha}$ are more common, the additional complication of stratifying soil $\mathrm{C}$ in the top $0.05 \mathrm{~m}$ layer under ZT management, where moisture is often limiting, is likely to limit its impact on soil biota. Similarly, an increased summer sorghum crop frequency resulting from risk minimisation strategies like skip row planting (Routley et al. 2003; Broad and Hammer 2004) may increase residue inputs compared to wheat in drier environments, but the combination of ZT and wide row spacing will result in extreme heterogeneity (both horizontally and vertically) of $\mathrm{C}$ inputs, and this will also limit impacts on the soil biota throughout the profile.

Our results suggest that cropped soils in the study area (except for the zone near the soil surface) are currently little more than a medium to hold water and provide physical support for plants. Their biological status is generally poor, and it is therefore not surprising that there was a poor correlation between various measures of the soil biota and growth responses in the glasshouse to pasteurisation. The reasons for the consistent pasteurisation response are not known, but it is possible that beneficial components of the biology are not diverse or active enough to modulate the effects of soil-borne pathogens. Future research should focus on testing this hypothesis and should also aim to demonstrate that changes in soil biological status in the field result in measurable impacts on parameters such as crop productivity, soil fertility, and disease severity.

\section{Acknowledgments}

The authors wish to acknowledge the assistance of Mrs Jan Wood and Mr John Cooper in the collection of field samples and the conduct of glasshouse trials and laboratory sample preparation. Matthew Ayres is acknowledged for his input into the soil analyses. We would also like to thank the many land owners and consultants (in particular Sid Cook and Jim Hunt from Landmark and Peter Mackenzie from AgVance) for access to properties across the region. The funding support of GRDC is also gratefully acknowledged.

\section{References}

Angersbach S, Earp R (2004) Molecular Probes PicoGreen ${ }^{\circledR}$ Assay Performed on BMG LABTECH POLARstar OPTIMA Microplate Reader. BMG LABTECH Application Note 103.

Angus JF, Gupta VVSR, Good AJ, Pitson GD (1999) Wheat yield and protein responses to anhydrous ammonia (Coldflo $\left.{ }^{\circledR}\right)$ and urea, and their effects on soil. Final Report of Project CSP169, Grains Research and Development Corporation, Canberra, ACT.

Anon. (2002) Australian agricultural assessment 2001, Vol 1. National Land and Water Resources Audit, Land and Water Australia, Turner, ACT.

Anon. (2004) AgSTATs 2001. Australian Bureau of Statistics, Canberra.

Arias ME, Gonzalez-Perez JA, Gonzalez-Vila FJ, Ball AS (2005) Soil health-a new challenge for microbiologists and chemists. International Microbiology 8, 13-21.

Bell MJ, Bridge BJ, Harch GR, Orange DN (1997) Physical rehabilitation of degraded Krasnozems using ley pastures. Australian Journal of Soil Research 35, 1093-1113. doi: 10.1071/S97005

Bell MJ, Moody PW, Yo SA, Connolly RD (1999) Using active fractions of soil organic matter as indicators of the sustainability of Ferrosol farming systems. Australian Journal of Soil Research 37, 279-287. doi: $10.1071 / \mathrm{S} 98064$

Biederbeck VO, Campbell CA, Ukaintetz H, Curtin D, Bouman OT (1996) Soil microbial and biochemical properties after ten years fertilisation with urea and anhydrous ammonia. Canadian Journal of Soil Science 76, 7-14.

Blair GJ, Lefroy RDB, Lisle L (1995) Soil carbon fractions based on their degree of oxidation, and the development of a carbon management index for agricultural systems. Australian Journal of Agricultural Research 46, 1459-1466. doi: 10.1071/AR9951459

Brennan JP, Murray GM (1998) 'Economic importance of wheat diseases in Australia.' (NSW Agriculture: Wagga Wagga, NSW)

Broad I, Hammer G (2004) Soil exploration by sorghum root systems in wide row cropping systems. In 'New directions for a diverse planet. Proceedings for the 4th International Crop Science Congress'. (Eds T Fischer, N Turner, J Angus, L McIntyre, M Robertson, A Borrell, D Lloyd) (ICSS: Brisbane, Qld) www.cropscience.org.au

Burgess LW, Backhouse D, Swan LJ, Esdaile RJ (1996) Control of Fusarium crown rot of wheat by late stubble burning and rotation with sorghum. Australasian Plant Pathology 25, 229-233. doi: 10.1071/AP96042

Cavigelli MA, Robertson GP, Klug MJ (1995) Fatty acid methyl ester (FAME) profiles as measures of soil microbial community structure. Plant and Soil 170, 99-113. doi: 10.1007/BF02183058

Chudleigh FC, Cox HW, Chapman VJ (2002) Modelling profitable and sustainable farming systems in Central Queensland. In 'Proceedings 46th Annual Conference, Australian Agricultural and Resource Economics Society Inc.'. Adelaide, S. Aust. (CD-ROM)

Dalal RC, Chan KY (2001) Soil organic matter in rainfed cropping systems of the Australian cereal belt. Australian Journal of Soil Research 39, 435-464. doi: 10.1071/SR99042

Dalal RC, Mayer RJ (1987) Long term trends in fertility of soils under continuous cultivation and cereal cropping in southern Queensland. VII. Dynamics of nitrogen mineralisation potentials and microbial biomass. Australian Journal of Soil Research 25, 461-472. doi: 10.1071/SR9870461 
Dalal RC, Probert ME (1997) Soil nutrient depletion. In 'Sustainable crop production in the sub-tropics - an Australian perspective'. (Eds AL Clarke, PB Wylie) pp. 42-63. (Queensland Department of Primary Industries: Toowoomba, Qld)

Dalal RC, Strong WM, Weston EJ, Cahill MJ, Cooper JE, Lehane KJ, King AJ, Gaffney J (1994) Evaluation of forage and grain legumes, no-till and fertilisers to restore fertility degraded soils. Transactions of the International Society of Soil Science 5a, 62-74.

Dalal RC, Strong WM, Weston EJ, Cooper JE, Lehane KJ, King AJ, Chicken CJ (1995) Sustaining productivity of a Vertisol at Warra, Queensland, with fertilisers, no-till or legumes. I. Organic matter status. Australian Journal of Experimental Agriculture 35, 903-913. doi: 10.1071/EA9950903

Doughton JA, Holford ICR (1997) Legumes. In 'Sustainable crop production in the sub-tropics - an Australian perspective'. (Eds AL Clarke, PB Wylie) pp. 235-257. (Queensland Department of Primary Industries: Toowoomba, Qld)

Duczek LJ, Wildermuth GB (1991) Populations of amoebae which feed on conidia and hyphae of Bipolaris sorokiniana in Queensland soils. Australasian Plant Pathology 20, 81-85. doi: 10.1071/APP9910081

Felton WL, Marcellos H, Martin RJ (1995) A comparison of three fallow management strategies for the long term productivity of wheat in northern New South Wales. Australian Journal of Experimental Agriculture 35, 915-921. doi: 10.1071/EA9950915

Fontvieille DA, Outaguerouine A, Thevenot DR (1991) Fluorescein diacetate hydrolysis as a measure of microbial activity in aquatic systems: application to activated sludges. Environmental Technology 13, 531-540.

Forster JC (1998) Soil physical analysis. In 'Methods in applied soil microbiology and biochemistry'. (Eds K Alef, P Nannipieri) pp. 105-121. (Academic Press: London)

Freebairn DM, Connolly RD, Dimes J, Wylie PB (1997) Crop sequencing. In 'Sustainable crop production in the subtropics - an Australian perspective'. (Eds AL Clarke, PB Wylie) pp. 289-305. (Queensland Department of Primary Industries: Toowoomba, Qld)

Gardner PA, Angus JF, Pitson GD, Wong PTW (1998) A comparison of six methods to control take-all in wheat. Australian Journal of Agricultural Research 49, 1225-1240. doi: 10.1071/A98050

Graham JH, Hodge NC, Morton JB (1995) Fatty acid methyl ester profiles for characterisation of Glomalean fungi and their endomycorrhizae. Applied and Environmental Microbiology 61, 58-64.

Isbell RF (1993) A classification system for Australian soils (third approximation). CSIRO Australia Division of Soils Technical Report 2/1993.

Islam KR, Weil RR (1998) Microwave irradiation of soil for routine measurement of microbial biomass carbon. Biology and Fertility of Soils 27, 408-416. doi: 10.1007/s003740050451

Johnson MJ, Lee KY, Scow KM (2003) DNA fingerprinting reveals links among agricultural crops, soil properties, and composition of soil microbial communities. Geoderma 114, 279-303. doi: 10.1016/S0016-7061(03)00045-4

Kirkegaard JA, Hocking PJ, Angus JF, Howe GN, Gardner PA (1997) Comparison of canola, Indian mustard and Linola in two contrasting environments. II. Break crop and nitrogen effects on subsequent wheat crops. Field Crops Research 52, 179-191. doi: 10.1016/S0378-4290(96)01057-X

Kirkegaard JA, Holland J, Moore K, Simpfendorfer S, Bambach R, Marcroft S, Holloway G (2003) Effect of previous crops on crown rot infection and yield of wheat. 'Proceedings of the 11th Australian Agronomy Conference'. Geelong, Vic. Available at: www.regional.org.au/au/asa/2003/c/6/kirkegaard.htm
Lester DW, Dowling CW (2001) Comparing grain yield and protein from pre-plant application of anhydrous ammonia and urea over four cereal crops. In 'Proceedings of the 10th Australian Agronomy Conference 2001'. Hobart, Tas. (Australian Institute of Agricultural Science and Technology: Carlton, Vic.) Available online at: www.regional.org.au/au/asa/2001/p/14/lester1.htm\#TopOfPage

Lester DW, Dowling CW, Birch CJ (2003) Fertilizer N and P application on two Vertosols of NE Australia: 1. Trends in bicarbonate extractable P. In 'Proceedings of 2nd International Symposium on Phosphorus Dynamics in the Soil-Plant Continuum'. Perth, Western Australia. (Ed. Z Rengel) pp. 204-205. (University of Western Australia: Crawley, W. Aust.)

McGhie WJ, Jacobs B, Heenan DP (1998) The impact of rotation, stubble management and tillage on the relative contribution of bacterial and fungal microbial biomass. In 'Proceedings of the 9th Australian Agronomy Conference'. Wagga Wagga. pp. 783-786. Available online at: www.regional.org.au/au/asa/1998/ 8/134mcghie.htm\#P1_127

Neate SM (1987) Plant debris in soil as a source of inoculum of Rhizoctonias in wheat. Transactions of the British Mycological Society 88, 157-162.

Olsson PA (1999) Signature fatty acids provide tools for determination of the distribution and interactions of mycorrhizal fungi in soil. FEMS Microbiology Ecology 29, 303-310.

Ophel Keller K, McKay A, Driver F, Curran J (1999) The cereal root disease testing service. In 'Proceedings of the First Soilborne Disease Symposium'. (Ed. RC Magarey) pp. 63-64. (Bureau of Sugar Experiment Stations: Brisbane, Qld)

Pankhurst CE, Blair BL, Magarey RC, Stirling GR, Bell MJ, Garside AL (2005) Effect of rotation breaks and organic amendments on the capacity of soils to develop biological suppression towards soil organisms associated with yield decline of sugarcane. Applied Soil Ecology 28, 271-282. doi: 10.1016/j.apsoil.2004.07.010

Pankhurst CE, Doube DM, Hawke BG, Dillon SJ, Williams PML (2000) Application of GC-FAME technology to the management of soil micro-organisms in cropping systems. Final Report for Project CSO170, Grains Research and Development Corporation, Canberra, ACT.

Pankhurst CE, Hawke BG, McDonald HJ, Kirby CA, Buckerfield JC, Michelsen P, O'Brien KA, Gupta VVSR, Doube BM (1995) Evaluation of soil biological properties as potential bioindicators of soil health. Australian Journal of Experimental Agriculture 35, 1015-1028.

Pankhurst CE, McDonald HJ, Hawke BG, Kirby JM (2002) Effect of tillage and stubble management on chemical and microbiological properties and the development of suppression towards cereal root disease in soils from two sites in NSW, Australia. Soil Biology and Biochemistry 34, 833-840. doi: 10.1016/S00380717(02)00014-7

Pankhurst CE, Yu S, Hawke BG, Harch BD (2001) Capacity of fatty acid profiles and substrate utilization patterns to describe differences in soil microbial communities associated with increased salinity or alkalinity at three locations in South Australia. Biology and Fertility of Soils 33, 204-217. doi: 10.1007/s003740000309

Peck DM, Thompson JP, Clewett TG, Haak MI (1993) The root lesion nematode Pratylenchus thornei survives extended clean fallows and builds up quickly with wheat cropping. In 'Proceedings of the Pratylenchus Workshop, 9th Biennial Conference of Australian Plant Pathology Society'. Hobart, Tas. pp. 24-27.

Radford B, Key AJ, Robertson LN, Thomas GA (1995) Conservation tillage increases soil water storage, soil animal populations, grain yield, and response to fertiliser in the semi-arid tropics. Australian Journal of Experimental Agriculture 35, 223-232. doi: 10.1071/EA9950223 
Rayment GE, Higginson FR (1992) 'Australian laboratory handbook of soil and water chemical analyses.' (Inkata Press: Sydney, NSW)

Roget DK, Coppi JA, Herdina, Gupta VVSR (1999) Assessment of suppression to Rhizoctonia solani in a range of soils across SE Australia. In 'Proceedings, First Australian Soilborne Disease Symposium'. (Ed. RC Magarey) pp. 129-130. (Bureau of Sugar Experiment Stations: Brisbane, Qld)

Roper MM, Gupta VVSR (1995) Management factors and soil biota. Australian Journal of Soil Research 33, 321-339. doi: 10.1071/SR9950321

Roper MM, Turpin JE, Thompson JP (1994) Nitrogenase activity $\left(\mathrm{C}_{2} \mathrm{H}_{2}\right.$ reduction) by free-living bacteria in soil in a long-term tillage and stubble management experiment on a vertisol. Soil Biology and Biochemistry 26, 1087-1091. doi: 10.1016/0038-0717(94)90125-2

Routley R, Broad I, McLean G, Whish J, Hammer G (2003) The effect of row configuration on yield reliability in grain sorghum: 1. Yield, water use efficiency and soil water extraction. In 'Solutions for a better environment. Proceedings 11th Australian Agronomy Conference'. Geelong, Victoria. (Australian Society of Agronomy: Carlton, Vic.) Available online at: www.regional.org.au/ au/asa/2003/c/9/routley.htm

Rovira AD (1990) The impact of soil and crop management practices on soil-borne root diseases and wheat yields. Soil Use and Management 6, 195-200.

Rovira AD (1994) The effect of farming practices on the soil biota. In 'Soil biota: Management in sustainable farming systems'. (Eds CE Pankhurst, BM Doube, VVSR Gupta, PR Grace) pp. 81-87. (CSIRO Australia)

Rowland LJ, Nguyen B (1993) Use of polyethylene-glycol for purification of DNA from leaf tissue of woody plants. BioTechniques 14, 734-736.

Salmond GR, Hare JM (2002) Annual Report for Project 3.1.07AC (Coordination and promotion of innovative farming systems research). Australian Cotton Co-operative Research Centre Annual Report 2001-02, Narrabri, NSW. p.45.

Sarathchandra SU, Ghani A, Yeates GW, Burch G, Cox NR (2001) Effect of nitrogen and phosphate fertilisers on microbial and nematode diversity in pasture soils. Soil Biology and Biochemistry 33, 953-964. doi: 10.1016/S0038-0717(00)00245-5

Stewart JB, Moran CJ, Wood JT (1999) Macropore sheath: quantification of plant root and soil macropore association. Plant and Soil 211, 59-67. doi: 10.1023/A:1004405422847

Stirling GR, Lodge GM (2005) A survey of Australian temperate pastures in summer and winter rainfall zones: soil nematodes, chemical and biochemical properties. Australian Journal of Soil Research 43, 887-904. doi: 10.1071/SR05079

Stirling GR, Blair BL, Pattemore JA, Garside AL, Bell MJ (2001) Changes in nematode populations on sugarcane following fallow, fumigation and crop rotation, and implications for the role of nematodes in yield decline. Australasian Plant Pathology 30, 323-335. doi: 10.1071/AP01044

Stirling GR, Stirling AM, Seymour NP, Bell MJ (2004) Use of free-living nematodes in soil food web diagnostics: An example from the Vertosols of the northern grain belt. In 'Proceedings of the 3rd Australasian Soilborne Diseases Symposium'. (Eds KM Ophel Keller, BH Hall) pp. 3-4. (South Australian Research and Development Institute: Adelaide, S. Aust.)

Tenuta M, Ferris H (2004) Sensitivity of nematode life-history groups to ions and osmostic tensions of nitrogenous solutions. Journal of Nematology 36, 85-94.

Thomas GA, Thompson JP, Amos RN (2003) A long term fallow management experiment on a Vertosol at Hermitage research station in southern Queensland, Australia. In 'Proceedings 16th Triennial Conference, International Soil Tillage Research Organisation'. Brisbane, Australia. pp. 1223-1228.
Thompson JP (1987) Decline of vesicular-arbuscular mycorrhizae in long fallow disorder of field crops and its expression in phosphorus deficiency of sunflower. Australian Journal of Agricultural Research 38, 847-862. doi: 10.1071/AR9870847

Thompson JP (1994) Inoculation with vesicular-arbuscular mycorrhizal fungi from cropped soil overcomes long-fallow disorder of linseed (Linum usitatissimum L.) by improving $\mathrm{P}$ and $\mathrm{Zn}$ uptake. Soil Biology and Biochemistry 26, 1133-1143. doi: 10.1016/00380717(94)90135-X

Thompson JP, Brennan PS, Clewett TG, Sheedy JG, Seymour NP (1999) Progress in breeding wheat for tolerance and resistance to root-lesion nematode (Pratylenchus thornei). Australasian Plant Pathology 28, 45-52. doi: 10.1071/AP99006

Thompson JP, Mackenzie J, Amos R (1995) Root-lesion nematode (Pratylenchus thornei) limits response of wheat not barley to stored moisture in the Hermitage long-term tillage trial. Australian Journal of Experimental Agriculture 35, 1049-1055. doi: 10.1071/EA9951049

Thoss V, Baird MS, Lock MA, Courty PV (2002) Quantifying the phenolic content of freshwaters using simple assays with different underlying reaction mechanisms. Journal of Environmental Monitoring 4, 270-275. doi: 10.1039/b107573j

Webb AA, Grundy MJ, Powell B, Littleboy M(1997) The Australian subtropical cereal belt: soils, climate and agriculture. In 'Sustainable crop production in the sub-tropics - an Australian perspective'. (Eds AL Clarke, PB Wylie) pp. 8-23. (Queensland Department of Primary Industries: Toowoomba, Qld)

Whitehead AG, Hemming JR (1965) A comparison of some quantitative methods of extracting some small vermiform nematodes from soil. Annals of Applied Biology 55, 25-38.

Wildermuth GB, Thompson JP, Robertson LN (1997) Biological change: diseases, insects and beneficial organisms. In 'Sustainable crop production in the sub-tropics - an Australian perspective'. (Eds AL Clarke, PB Wylie) pp. 112-130. (Queensland Department of Primary Industries: Toowoomba, Qld)

Wilson-Rummenie AC, Radford BJ, Robertson LN, Simpson GB, Bell KL (1999) Reduced tillage increases population density of soil macrofauna in a semi-arid environment in central Queensland. Environmental Entomology 28, 163-172.

Yeates GW (2003) Nematodes as soil indicators:functional and biodiversity aspects. Biology and Fertility of Soils 37, 199-210.

Yeates GW, Bongers T, de Goede RGM, Freckman DW, Georgieva SS (1993) Feeding habits in soil nematode families and genera - an outline for soil ecologists. Journal of Nematology 25, 315-331.

Yeates GW, King KL (1997) Soil nematodes as indicators of the effect of management in grasslands in the New England Tablelands (NSW): Comparison of native and improved grasslands. Pedobiologia 41, 526-536.

Zak DR, Ringelberg DB, Randlett DL, White DC, Curtis PS (1996) Soil microbial communities beneath Populus grandidentata grown under elevated atmospheric $\mathrm{CO}_{2}$. Ecological Applications 6, 257-262. doi: 10.2307/2269568

Zelles L (1999) Fatty acid patterns of phospholipids and lipopolysaccharides in the characterisation of microbial communities in soil: a review. Biology and Fertility of Soils 29, 111-129. doi: 10.1007/s003740050533

Zhou J, Bruns MA, Tiedje JM (1996) DNA recovery from soils of diverse composition. Applied and Environmental Microbiology 62, 316-322.

Manuscript received 16 September 2005, accepted 15 May 2006 